\title{
11 \\ Nitrogen Transformations in Submerged Soils
}

\author{
R.J. Buresh \\ International Rice Research Institute, Manila, Philippines \\ K. Ramesh Reddy \\ University of Florida-IFAS, Gainesville, Florida \\ Chris van Kessel \\ University of California, Davis
}

Soils with continuous or intermittent submergence by water are widely distributed worldwide. They occur in a range of ecosystems including rice (Oryza sativa L.) fields, wetlands, estuaries, and floodplains. Such ecosystems often occur at low elevation in the landscape and are poorly drained with high retention of water. In addition, some upland areas with poor drainage can undergo periodic submergence and soil saturation. Moreover, the sediments in ocean, lake, and stream bottoms have similar biogeochemical and physical characteristics and $\mathrm{N}$ transformations as submerged agricultural soils.

Rice fields surrounded by earthen levees to retain rain and irrigation water and ensure soil submergence are one of the world's major agricultural ecosystems. Rice is a staple food for nearly half the world's population, and about $95 \%$ of the global rice production occurs on fields with soil submerged during at least part of the rice-cropping period. The sustained productivity of this rice ecosystem, which ensures production of sufficient food for a growing world population, relies heavily on the input and management of $\mathrm{N}$.

Nitrogen transformations in submerged soils are markedly different from those in drained, aerated soils. These differences affect the prevalent soil microorganisms and microbial activities and the turnover, availabilility, and losses of $\mathrm{N}$. To deal with the differences in $\mathrm{N}$ transformations between submerged and drained soils it is necessary to understand the biogeochemical conditions existing in submerged soils. This chapter is an update of an earlier review by Patrick (1982).

\section{Properties of Submerged Soils}

A unique feature of submerged soils, affecting $\mathrm{N}$ transformations, is the depletion of oxygen $\left(\mathrm{O}_{2}\right)$ throughout most of the root zone (Ponnamperuma, 1972).

Copyright @ $\odot$ 2008. American Society of Agronomy, Crop Science Society of America, Soil Science Society of America, 677 S. Segoe Rd., Madison, WI 53711, USA. Nitrogen in Agricultural Systems, Agronomy Monograph 49. 
When a soil is submerged with water, the supply of $\mathrm{O}_{2}$ into the soil is greatly reduced because the diffusivity of $\mathrm{O}_{2}$ in water is about 10,000 times less than its diffusivity in air. As a result of this tremendous decrease in gas exchange between air and soil after submergence, the supply of $\mathrm{O}_{2}$ cannot meet the demand of aerobic organisms. Within hours of soil submergence, facultative microorganisms predominate. After a few hours to days, anaerobic microorganisms accumulate in soil layers. Facultative and anaerobic organisms use oxidized soil substrates as electron acceptors in their respiration, thus reducing the soil components in a sequence predicted by thermodynamics.

The water column overlying a submerged soil contains dissolved $\mathrm{O}_{2}$, which typically moves a small distance into the soil before it is depleted. A submerged soil is consequently differentiated, based on $\mathrm{O}_{2}$ penetration, into an aerobic (oxidized) surface layer and an underlying anaerobic (reduced) layer. The thickness of this oxidized surface layer of soil is determined by the net effect of $\mathrm{O}_{2}$ supply from the overlying water and the consumption rate of $\mathrm{O}_{2}$ in soil. A high $\mathrm{O}_{2}$ consumption rate in soil results in a thin oxidized soil layer of about $1 \mathrm{~mm}$ in thickness. A low $\mathrm{O}_{2}$ consumption rate results in a thicker oxidized layer.

The consumption of $\mathrm{O}_{2}$ in soil is directly related to the concentration of an energy source, including electron donors. Soils with an appreciable supply of readily decomposable organic matter, a typical electron donor, usually have a thin oxidized soil layer because of the high $\mathrm{O}_{2}$ consumption. When decomposable organic matter is high in the overlying water or at the soil surface, the dissolved $\mathrm{O}_{2}$ in water can be consumed before it reaches the soil surface. In such case, there is no surface aerobic soil layer (DeLaune et al., 1979). This condition is typically transient with the continuous supply of $\mathrm{O}_{2}$ from the atmosphere into the overlying water eventually satisfying the $\mathrm{O}_{2}$ demand in the water column and $\mathrm{O}_{2}$ then diffusing into soil.

Plants adapted to submerged soils have developed gas exchange processes enabling $\mathrm{O}_{2}$ and other gases to pass through the plant's emergent parts into the root zone. In many of these plants, including rice, $\mathrm{O}_{2}$ is transported through porous internal aerenchyma tissue to roots, where most of the $\mathrm{O}_{2}$ is consumed in root respiration. Some of the $\mathrm{O}_{2}$ reaching the roots escapes into the surrounding soil and oxidizes reduced components. This creates a thin aerobic zone surrounded by a much more extensive anaerobic soil zone.

The aerobic zone surrounding plant roots and on the surface of submerged soils can often be distinguished by a thin yellowish layer associated with oxidized iron $\left(\mathrm{Fe}^{3+}\right)$. The aerobic layer is characterized by the presence of high redox potential, whereas the adjacent anaerobic soil zone is associated with low or more negative redox potential. The adjoining aerobic and anaerobic soil zones support a diversity of microbial populations and associated metabolic activities. Aerobic microorganisms are distributed in submerged soil based on the presence of $\mathrm{O}_{2}$ and facultative and obligate anaerobic microorganisms are distributed based on the presence of electron acceptors for their respiration. In the absence of $\mathrm{O}_{2}$, aerobic microorganisms die or remain inactive, while anaerobic microorganisms proliferate. Anaerobic microorganisms use oxidized soil components, such as mineral constituents containing $\mathrm{Fe}^{3+}$ and $\mathrm{Mn}^{4+}$ and dissimilation products of soil organic matter (SOM) as electron acceptors in their respiration.

Lowland rice fields in Asia are globally the main agricultural ecosystem with submerged soils. These rice fields are typically flooded before plowing and harrowing for rice production. This process of tillage at soil saturation, referred to as 


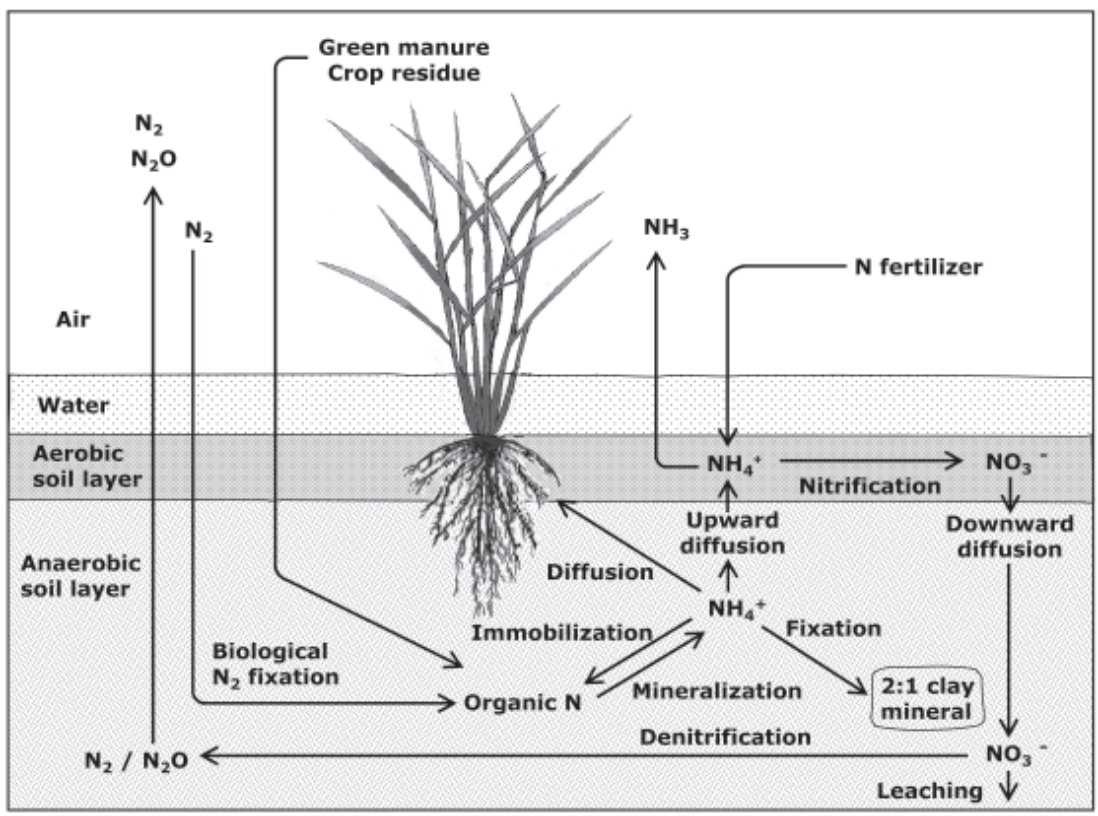

Fig. 11-1. A schematic diagram of $\mathrm{N}$ transformations in a submerged soil.

puddling, destroys soil aggregates. Puddling eliminates water transmission pores, reduces the percolation rate, and reduces gas exchange between the soil and outer atmosphere (Sharma and De Datta, 1986). As a result of the reduced gas exchange, $\mathrm{O}_{2}$ entering the soil is rapidly depleted near the soil surface leading to a relatively thin aerobic soil layer. Puddling also results in the formation of a hardpan that restricts downward water flow, thereby helping to maintain soil saturation and reduce loss of nutrients by leaching. The rice crop is established either by transplanting or by broadcasting of germinated seeds on flooded or saturated soil, and the soil is maintained flooded or saturated throughout most or all the period of rice growth.

Some lowland rice is also grown on nonpuddled soils, but in these production systems the soil is typically submerged at least part of the time. One method of rice crop establishment, including in the USA, is to sow germinated seeds onto nonpuddled, saturated, or flooded soil. In such case, the rice field is irrigated and left flooded for much of the growing period. Another method, practiced in some temperate irrigated rice production systems and some tropical rainfed lowland ecosystems in Asia, is to establish rice by seeding on nonpuddled, nonsaturated soil. The soil becomes submerged after crop establishment by either irrigation or water accumulating from monsoon rains.

On an annual basis, most lowland rice fields undergo alternate submergence and drying. The soils are submerged for at least part of the period during production of rice, but they typically dry and become aerated during the period between rice crops. At this time the soil is normally either left fallow or grown with upland crops. In California, rice fields are often reflooded during the winter months between rice crops to increase residue decomposition and provide a habitat for migratory waterfowl. In rainfed ecosystems and irrigated environments with insuf- 
ficient or irregular water supply, the soils can also undergo alternate drying and rewetting during rice growth. In some irrigated rice ecosystems with good water control in China, farmers drain rice fields during the vegetative growth phase. This midseason drainage and short-term drying of the submerged soil can control excessive tillering of rice, help regulate leaf area of rice at desired levels, and improve root activity. The midseason drainage can, however, also influence $\mathrm{N}$ transformations and $\mathrm{N}$ loss processes.

\section{Nitrogen Transformations}

The forms of $\mathrm{N}$ present in submerged soils are generally similar to those in aerated soils; but the relative magnitude of the $\mathrm{N}$ forms, particularly nitrate $\left(\mathrm{NO}_{3}^{-}\right)$ and ammonium $\left(\mathrm{NH}_{4}^{+}\right)$, and $\mathrm{N}$ transformation are markedly affected by the oxidation status of soil (Fig. 11-1). Nitrate is the dominant form of inorganic $\mathrm{N}$ in drained, aerated soils; whereas $\mathrm{NH}_{4}^{+}$is the dominant and stable form of inorganic $\mathrm{N}$ that accumulates in submerged soils. When $\mathrm{O}_{2}$ is present, such as in aerated soils and in the localized aerobic zone of submerged soils, $\mathrm{NH}_{4}^{+}$is converted to $\mathrm{NO}_{3}^{-}$. This $\mathrm{NO}_{3}^{-}$is not readily denitrified (reduced) in the aerated soil, and it can consequently accumulate. In the anaerobic zone of submerged soils, which constitutes the vast proportion of a submerged soil, $\mathrm{NH}_{4}^{+}$is not converted to $\mathrm{NO}_{3}^{-}$. Nitrate moving into the anaerobic zone or residing in the soil before submergence and depletion of $\mathrm{O}_{2}$ can be readily denitrified.

Nitrogen is typically the main limiting nutrient in the production of lowland rice, and use of $\mathrm{N}$ fertilizer is vital for the sustained production of sufficient rice to meet demand. About $20 \%$ of the global production of fertilizer $\mathrm{N}$ is used in rice production systems that experience soil submergence (Dat Tran, personal communication, 2001). Yet the use efficiency of this fertilizer $\mathrm{N}$ by the crop is typically low, due at least in part to losses of the applied fertilizer $\mathrm{N}$ arising from unique features of submerged soils as compared with aerated soils.

The main $\mathrm{N}$ transformation processes in submerged soils-as in aerated soils - are mineralization, immobilization, nitrification, denitrification, ammonia $\left(\mathrm{NH}_{3}\right)$ volatilization, and biological $\mathrm{N}_{2}$ fixation. Soil submergence modifies these processes, and a unique feature of submerged soils is the simultaneous formation and loss of $\mathrm{NO}_{3}^{-}$, occurring within the adjoining aerobic and anaerobic soil zones. Submerged soils as compared with aerated soils are favorable environments for loss of $\mathrm{N}$ by nitrification-denitrification, $\mathrm{NH}_{3}$ volatilization, and for addition of $\mathrm{N}$ via biological $\mathrm{N}_{2}$ fixation (BNF).

\section{Mineralization and Immobilization}

Mineralization, or more specifically ammonification - the conversion of soil organic $\mathrm{N}$ to ammonium - supplies plant-available $\mathrm{N}$ in submerged agricultural soils. Even with high-yielding rice crops receiving high rates of fertilizer $N,>50 \%$ of the total $\mathrm{N}$ assimilated by the crop typically originates from the breakdown of soil organic N compounds (Mikkelsen, 1987; Cassman et al., 1998). This breakdown of organic $\mathrm{N}$ in submerged soils is characterized by anaerobic decomposition, which involves different microorganisms and endproducts than aerobic decomposition. Ammonium accumulates in anaerobic decomposition due to the absence of $\mathrm{O}_{2}$, which is required for conversion of $\mathrm{NH}_{4}^{+}$to $\mathrm{NO}_{3}^{-}$. 
Microbial decomposition of organic matter in aerated soil is accomplished by a wide range of microorganisms including fungi, heterotrophic bacteria, and actinomycetes. Respiration by these organisms is associated with high energy release, and the decomposition of substrates progresses rapidly with evolution of $\mathrm{CO}_{2}$. As cell synthesis proceeds, there is a heavy demand for mineral nutrients, particularly $\mathrm{N}$. Decomposition in the bulk volume of a submerged soil, on the other hand, depends on a relatively restricted bacterial microflora. These anaerobes operate at a lower energy level and are less efficient than aerobes as a consequence of incomplete decomposition of carbohydrates and synthesis of fewer microbial cells per unit of organic C degraded (Waksman, 1929; Payne, 1970). The processes of both decomposition and cell synthesis are consequently slower under anaerobic than aerobic conditions. In aerobic soil the main endproducts of decomposition are $\mathrm{CO}_{2}$, $\mathrm{NO}_{3}{ }^{-}, \mathrm{SO}_{4}{ }^{2-}$, water, and resistant residues. The main endproducts of anaerobic decomposition are $\mathrm{CO}_{2}, \mathrm{CH}_{4}$, organic acids, $\mathrm{NH}_{4}^{+}, \mathrm{H}_{2} \mathrm{~S}$, and resistant residues (Acharya, 1935a, 1935b; Tusneem and Patrick, 1971).

The breakdown of SOM and plant residues is typically slower in submerged than aerobic soil (Acharya, 1935c; Villegas-Pangga et al., 2000). Hence, a lower gross $\mathrm{N}$ mineralization rate would be expected in submerged soils as compared with aerobic soils. Gross N immobilization is characteristically lower in submerged soils because of the low metabolic requirement of anaerobic microorganisms for $\mathrm{N}$ (Acharya, 1935a). The net effect of the lower gross mineralization and lower gross immobilization is often a higher net $\mathrm{N}$ mineralization in submerged than aerobic soils, leading to higher rates of inorganic $\mathrm{N}$ release in submerged soil (Tusneem and Patrick, 1971). Because of the low $\mathrm{N}$ requirement of anaerobic metabolism, the net release of inorganic $\mathrm{N}$ from decomposing plant residue would expectedly occur at a higher $\mathrm{C} / \mathrm{N}$ in submerged rather than aerobic soil. Incubations with 20 soils without residue confirmed lower gross $\mathrm{N}$ immobilization in submerged rather than aerobic conditions (Wang et al., 2001b). Net N mineralization was not always higher under submerged rather than aerobic conditions in this study, but it is possible the observed instances of lower net $\mathrm{N}$ mineralization with submerged soil resulted from higher $\mathrm{N}$ loss in submerged soil (Wang et al., 2001b). The net buildup of inorganic $\mathrm{N}$ in submerged soils is reportedly higher in the presence than the absence of rice plants. The influence of the rice plant depends on rice genotype (Ghosh and Kashyap, 2003) and supposedly involves more processes than merely a reduction in N loss (Kundu and Ladha, 1997).

Microbes in rice soils are an important temporary sink for $\mathrm{N}$ applied as fertilizers and residues (Bird et al., 2001, 2003). In a series of experiments using ${ }^{15} \mathrm{~N}$ labeled residues and fertilizers in a temperate rice system in California, mobile humic acid and microbial biomass became the primary active sink for sequestered ${ }^{15} \mathrm{~N}$ following the incorporation or burning of rice residues for $4 \mathrm{yr}$. About $30 \%$ of the fertilizer ${ }^{15} \mathrm{~N}$ recovered in the soil was in the mobile humic acid fraction and about $20 \%$ was in microbial biomass (Bird et al., 2002). The half-life of immobilized ${ }^{15} \mathrm{~N}$ was significantly lower for microbial biomass $(0.65 \mathrm{yr})$ than for mobile humic acid (8.9 yr) and fulvic acid $(6.9 \mathrm{yr})$, and microbial biomass ${ }^{15} \mathrm{~N}$ was the main source of ${ }^{15} \mathrm{~N}$ recovered by the following rice crop (Eagle et al., 2001; Bird et al., 2002).

The total amount of microbial biomass $\mathrm{N}$ in a temperate rice system in California ranged from $45 \mathrm{~kg} \mathrm{~N} \mathrm{ha}^{-1}$ during the winter months to $120 \mathrm{~kg} \mathrm{~N} \mathrm{ha}^{-1}$ during the growing season, and the incorporation of residues significantly increased microbial 
biomass N (Bird et al., 2001). Microbial biomass N by contrast in a continuous doublecropped rice system in the Tropics was lower and remained relatively stable at about 20 to $35 \mathrm{~kg} \mathrm{~N} \mathrm{ha}^{-1}$ throughout the growing season (Witt et al., 1998). In this study, microbial biomass $\mathrm{N}$ was not strongly affected by residue incorporation or fertilizer $\mathrm{N}$ application. Even though microbial activity influenced residue decomposition and the net release and availability of $\mathrm{N}$, microbial biomass $\mathrm{N}$ was a poor indicator of $\mathrm{N}$ dynamics and availability of $\mathrm{N}$ to the rice crop (Witt et al., 1998, 2000a).

Many studies have examined relationships between measurements of net $\mathrm{N}$ mineralization and the $\mathrm{N}$ accumulation or yield of rice grown on submerged soil. In a number of instances, direct relationships were reported between laboratory measurements of "plant-available N" and the N content or yield of rice (Dolmat et al., 1980; Kai et al., 1984; Manguiat et al., 1994). The total accumulation of $\mathrm{N}$ by rice in the absence of fertilizer $\mathrm{N}$ has increasingly been used as a field-based measurement of soil N supply, referred to as soil N-supplying capacity (SNSC) or indigenous N supply (INS) (Olk et al., 1999b; Dobermann et al., 2003). Studies in the 1990s, highlighted the high spatial and temporal variability associated with fieldmeasured INS, based on total accumulation of $\mathrm{N}$ by rice in zero- $\mathrm{N}$ plots (Cassman et al., 1996b). Field-measured INS is often not correlated with SOM, laboratory measurements of soil $\mathrm{N}$ availability, or field measurements of inorganic soil $\mathrm{N}$ (Cassman et al., 1996b; Adhikari et al., 1999), and even when relationships exist, the measured soil parameters explain only a small portion of the variation in rice yield in zero-N plots (Yadav, 2003). These findings highlight the importance of sitespecific management of fertilizer $\mathrm{N}$, in which the times and rates of $\mathrm{N}$ fertilization are dynamically adjusted for variations in INS (Cassman et al., 1996c; Dobermann et al., 2002).

Whereas lowland rice soils are submerged for all or part of the rice-growing season, they typically are dry and become aerobic between rice crops when fields are fallow or upland crops are grown. In some parts of Asia, access to irrigation has enabled intensification of rice cropping with production of two and three rice crops per year. Under such conditions the period of soil submergence is prolonged and soil aeration between crops decreases or disappears. Prolonged soil submergence promotes $\mathrm{C}$ and $\mathrm{N}$ sequestration, leading to maintenance or buildup of SOM (Cassman et al., 1995; Bronson et al., 1997a; Witt et al., 2000b; Pampolino et al., 2008).

Prolonged soil submergence and anaerobic soil conditions can, however, also promote a buildup of less-decomposed substances, which become incorporated into young SOM fractions. Prolonged duration of soil submergence increased phenolic content of SOM and increased mobile humic acid and calcium humate content, which represented about 20 to $25 \%$ of the total SOM in intensively cultivated tropical rice soil (Olk et al., 1996, 1998, 1999a; Bao Ve et al., 2004a, 2004b). Concern was raised that a buildup of phenolic compounds originating from less humification could immobilize $\mathrm{N}$ abiotically, thereby reducing the rate of net $\mathrm{N}$ mineralization (Olk et al., 2000, 2007). An analysis of soils from intensively cropped longterm experiments in the Philippines did not indicate formation of heterocyclic $\mathrm{N}$ or other aromatic forms of $\mathrm{N}$ arising from long-term continuous cropping of rice on submerged soils (Mahieu et al., 2000). Long-term yield trends in these experiments reveal no yield decline in the past 10 to $20 \mathrm{yr}$ in zero-N plots receiving other nutrients, thereby suggesting no decline in INS (Padilla, 2001). Soil drying immediately after rice harvest has been proposed as a practice to prevent a net decline in N-supplying capacity arising from abiotic immobilization of N (Olk et al., 2007); 
but recent field research consistently found no net increase in soil $\mathrm{NH}_{4}^{+}$or INS following soil drying rather than continuous soil submergence between rice crops with and without the retention of rice residues (Thuy, 2004; Buresh et al., unpublished data, 2007). Greater inputs of N during continuous soil submergence via $\mathrm{BNF}$, biological $\mathrm{N}$ mineralization, and irrigation water matched or exceeded any decline in N-supplying capacity arising from abiotic immobilization of $\mathrm{N}$.

Soil submergence during the fallow winter months in a temperate rice system in California has been promoted to provide a habitat for migratory waterfowl. The inclusion of an anaerobic period by flooding the fields had no significant effect on young SOM fractions as determined by the mobile humic and fulvic acid contents. Two relative short periods of soil aeration at the start and finish of the winter flooding, which presumably enable aerobic microbial communities to flourish, were sufficient for the degradation of any accumulation of abiotically immobilized $\mathrm{N}$ during the periods of soil submergence (Bird et al., 2002).

\section{Ammonia Volatilization}

Ammonia volatilization is now recognized as a major process by which fertilizer $\mathrm{N}$ is lost from rice fields with submerged or saturated soils. A substantial portion of the fertilizer $\mathrm{N}$ broadcast into the floodwater of rice fields or incorporated into puddled soils before rice establishment can accumulate in the floodwater as ammoniacal $\mathrm{N}\left(\mathrm{NH}_{4}^{+}+\mathrm{NH}_{3}\right)$ within the week after $\mathrm{N}$ application. Urea, a common fertilizer for rice in Asia, is rapidly hydrolyzed within the week after application to submerged soils (Fillery et al., 1984). Ammoniacal $N$ originating from the hydrolyzed urea accumulates in floodwater, and the peak concentration of ammoniacal $\mathrm{N}$ in the floodwater of tropical rice fields typically occurs within 1 to $5 \mathrm{~d}$ after urea application. High concentrations of ammoniacal $\mathrm{N}$ together with high floodwater $\mathrm{pH}$ and temperature favor loss of added fertilizer $\mathrm{N}$ by $\mathrm{NH}_{3}$ volatilization (Vlek and Stumpe, 1978; Cai, 1997).

The magnitude of $\mathrm{NH}_{3}$ loss from submerged soils is directly related to the content of aqueous $\mathrm{NH}_{3}$ or partial pressure of ammonia $\left(\mathrm{\rho NH}_{3}\right)$ in water at the interface with the atmosphere. Aqueous $\mathrm{NH}_{3}$ as a fraction of total ammoniacal $\mathrm{N}$ is directly influenced by water $\mathrm{pH}$ and temperature. Aqueous $\mathrm{NH}_{3}$ is negligible below $\mathrm{pH} 7.5$, but it increases rapidly from $\mathrm{pH} 7.5$ to 10 . At $\mathrm{pH} 9.2$ about $50 \%$ of the ammoniacal $\mathrm{N}$ in water is present as $\mathrm{NH}_{3}$ (Vlek and Craswell, 1981). Aqueous $\mathrm{NH}_{3}$, at a constant ammoniacal $\mathrm{N}$ concentration and $\mathrm{pH}$, increases linearly with temperature, resulting in nearly a fourfold increase with a change in temperature from 10 to $40^{\circ} \mathrm{C}$ (Vlek and Craswell, 1981). Water $\mathrm{pH}$ is, however, a more important factor influencing $\mathrm{NH}_{3}$ loss than temperature (Jayaweera and Mikkelsen, 1990).

Photosynthetic activity by aquatic biomass in floodwater and on the surface of saturated soil results in depletion of $\mathrm{CO}_{2}$ during the daytime and an accompanying elevation in water $\mathrm{pH}$. Floodwater $\mathrm{pH}$ typically displays a diurnal pattern synchronized with the cycle of photosynthesis and net respiration or the depletion and addition of $\mathrm{CO}_{2}$ to floodwater (Mikkelsen et al., 1978). Elevations in the midday $\mathrm{pH}$ of floodwater to above 9 in the week following $\mathrm{N}$ fertilization have commonly been reported for puddled rice soils in the Tropics (Fillery et al., 1986a). Photosynthetic activity by aquatic biomass in the floodwater and the associated elevation in midday $\mathrm{pH}$ of floodwater are typically most pronounced in the $3 \mathrm{wk}$ 
after rice establishment when algal growth can be favored by basal applications of fertilizer, particularly $\mathrm{P}$, and minimal shading from rice plants.

Ammonia loss from fertilizer $\mathrm{N}$ applied to young rice increases linearly with wind speed and $\mathrm{\rho NH}_{3}$ (Fillery et al., 1984). Increasing wind speed enhances $\mathrm{NH}_{3}$ loss by accelerating the transfer of $\mathrm{NH}_{3}$ away from the water-atmosphere interface, thus maintaining a gradient in $\mathrm{NNH}_{3}$ between the water and adjoining atmosphere. Ammonia loss can be reduced with rice establishment practices that reduce wind speed near the floodwater surface. Young broadcast-seeded rice has been reported to have lower wind speed at 3 to $10 \mathrm{~cm}$ above floodwater and lower associated $\mathrm{NH}_{3}$ loss from applied fertilizer $\mathrm{N}$ than young transplanted rice (De Datta et al., 1991). The denser plant population and greater surface cover with broadcast seeded rice, which restricted gas exchange at the floodwater-atmosphere interface, presumably accounted for the lower ammonia loss.

The magnitude of $\mathrm{NH}_{3}$ loss at a given wind speed follows diurnal patterns that parallel the diurnal fluctuations in floodwater $\mathrm{pH}$, which are directly related to $\rho \mathrm{NH}_{3}$. Ammonia loss, floodwater $\mathrm{pH}$, and $\rho \mathrm{NH}_{3}$ typically peak at about 1200 to $1400 \mathrm{~h}$ and are lowest overnight. The $\mathrm{\rho NH}_{3}$ can be calculated from measured ammoniacal N, temperature, and pH in floodwater (Denmead et al., 1982). Use of calculated $\mathrm{\rho NH}_{3}$ together with measured wind speed at one height in a rice field provides a simple technique for approximating the relative $\mathrm{NH}_{3}$ loss among fertilizer N sources and management practices (Freney et al., 1985).

Ammonia volatilization was generally not considered an important $\mathrm{N}$ loss process in submerged agricultural soils before the mid-1970s. Research in the mid1970s, however, created awareness that $\mathrm{NH}_{3}$ volatilization might be a mechanism for appreciable rapid loss of fertilizer $\mathrm{N}$ and highlighted the need for quantification of the importance of $\mathrm{NH}_{3}$ volatilization in rice fields (Bouldin and Alimagno, 1976; Mikkelsen et al., 1978; Vlek and Craswell, 1979). Micrometeorological techniques enabled the direct field measurement of $\mathrm{NH}_{3}$ loss without disrupting natural environmental conditions. These techniques overcame the uncertainties regarding the reliability of $\mathrm{NH}_{3}$ loss measurements conducted with static or forced-air-exchange enclosures that disrupted processes influencing the exchange of gases at the floodwater-air interface. The first use of the micrometeorological technique to directly quantify $\mathrm{NH}_{3}$ loss from an irrigated rice field was at a site in the Philippines, which was fertilized with ammonium sulfate (Freney et al., 1981). The measured losses of $\mathrm{NH}_{3}$ were relatively small (5-11\% of applied $\mathrm{N}$ ). A series of subsequent studies focused on urea, the main $\mathrm{N}$ fertilizer for rice in Asia and a source generally prone to higher $\mathrm{NH}_{3}$ loss than ammonium sulfate.

Numerous micrometeorological measurements were conducted at diverse sites in the 1980s to quantify the effect of various methods, times, and rates of urea application on loss of applied urea N (De Datta and Buresh, 1989). The directly measured losses started within a few hours after $\mathrm{N}$ application and ranged up to $>50 \%$ of applied urea $\mathrm{N}$ within 7 to $10 \mathrm{~d}$ after $\mathrm{N}$ application. Ammonia loss was generally greater when broadcast to young rice within $3 \mathrm{wk}$ after transplanting than to older rice near the panicle initiation stage. In a series of experiments in the Philippines, directly measured $\mathrm{NH}_{3}$ loss accounted for 27 to $56 \%$ of the urea $\mathrm{N}$ broadcast into floodwater at 10 to $21 \mathrm{~d}$ after transplanting (Fillery et al., 1984; Fillery and De Datta, 1986; De Datta et al., 1989). Ammonia loss at panicle initiation in contrast represented only 10 to $15 \%$ of the applied urea N (Fillery et al., 1984). The lower $\mathrm{NH}_{3}$ loss from urea applied to older rice arises from greater shading of 
the floodwater by the rice canopy, which reduces photosynthetic activity of the aquatic biomass thereby reducing $\mathrm{CO}_{2}$ depletion and the associated elevation in $\mathrm{pH}$ and $\mathrm{\rho NH}_{3}$. The larger canopy of the rice plant might also reduce $\mathrm{NH}_{3}$ loss by restricting gas exchange at the floodwater-atmosphere interface (Humphreys et al., 1988).

Incorporating urea before transplanting rather than broadcasting into floodwater at 10 to $21 \mathrm{~d}$ after transplanting often reduces $\mathrm{NH}_{3}$ loss (De Datta et al., 1989). The loss of $\mathrm{NH}_{3}$ from basal incorporated urea is reportedly less when floodwater is first removed and urea is broadcast and incorporated into saturated soil with no floodwater rather than broadcast and incorporated with standing floodwater (De Datta et al., 1987b, 1989). Tillage to incorporate fertilizer is, however, typically more energy demanding in the absence of floodwater. Implements available to Asian rice farmers are moreover only partially effective in reducing the buildup of ammoniacal $\mathrm{N}$ and $\mathrm{\rho NH}_{3}$ in floodwater (Padilla et al., 1990), and $\mathrm{N}$ losses from incorporated urea can still remain substantial under farmers' practices. The crop requirement for fertilizer $\mathrm{N}$ is small in the 2 to $3 \mathrm{wk}$ following transplanting or sowing rice, and Asian rice farmers were reluctant to adopt the incorporation of fertilizer $\mathrm{N}$ before transplanting or sowing rice (Fujisaka, 1994).

Ammonia volatilization is now well recognized as a major pathway for loss of fertilizer $\mathrm{N}$ applied to lowland rice fields (Zhu, 1997; Cai et al., 2002). The key to curbing this $\mathrm{NH}_{3}$ loss is to reduce $\mathrm{\rho NH}_{3}$ in water at the water-atmosphere interface of saturated or submerged soils. This can be achieved by preventing an elevation in water $\mathrm{pH}$, restricting gas exchange at the water-atmosphere interface, or preventing the buildup of ammoniacal N (Simpson et al., 1988). The use of algicide can restrict the elevation in floodwater $\mathrm{pH}$ and reduce buildup of $\rho \mathrm{NH}_{3}$ following $\mathrm{N}$ fertilization because floodwater $\mathrm{pH}$ is largely associated with the photosynthetic activity of algae (Chaiwanakupt et al., 1996). The use of algicide, however, can result in increased ammoniacal $\mathrm{N}$ in floodwater (Muirhead et al., 1989) because algae when present assimilate some ammoniacal N (Meyer et al., 1989). Films of organic compounds (Cai et al., 1987), algal scum (Zhu et al., 1989), and azolla (Vlek et al., 1995; Mandal et al., 1999; de Macale and Vlek, 2004) on the surface of floodwater have been shown to reduce $\mathrm{NH}_{3}$ loss by restricting the transfer of ammonia from floodwater to the overlying atmosphere. Azolla can also assimilate excess fertilizer $\mathrm{N}$ during early crop growth stages when the supply of $\mathrm{N}$ from fertilizer exceeds crop demand, and then subsequently cycle this fertilizer $\mathrm{N}$ to the rice through mineralization of azolla $\mathrm{N}$ when the crop demand for $\mathrm{N}$ is higher (Cisse and Vlek, 2003a, 2003b).

The buildup of ammoniacal $\mathrm{N}$ in floodwater can be reduced by more effective incorporation and placement of fertilizer N into puddled soils (De Datta et al., 1987b, 1989; Schnier et al., 1990, 1993; Devasenapathy and Palaniappan, 1996), application of fertilizer $\mathrm{N}$ immediately before rather than after permanent flooding in nonpuddled soils (Bacon et al., 1988; Humphreys et al., 1992), controlled release fertilizers (Oertli, 1980), and urease inhibitors (Buresh et al., 1988a, 1988b; Byrnes and Amberger, 1989; Freney, 1997). The application of fertilizer N immediately before rather than $14 \mathrm{~d}$ before permanent flooding reduces $\mathrm{NH}_{3}$ loss during production of dry-seeded rice on nonpuddled soils (Griggs et al., 2007). Deep placement of $\mathrm{N}$ fertilizer to minimize $\mathrm{N}$ loss was first reported in Japan (Mitsui, 1955), and it has since received considerable research attention (Cao et al., 1983; De Datta et al., 1987a; Savant et al., 1992). Urease inhibitors offer the attractive option of adding 
a small quantity of chemical additive to urea that slows urea hydrolysis and prevents a buildup of ammoniacal $\mathrm{N}$ in floodwater.

\section{Nitrification-Denitrification}

Nitrification - the biological conversion of $\mathrm{NH}_{4}^{+}$to $\mathrm{NO}_{3}{ }^{-}$-requires free $\mathrm{O}_{2}$. As a result it is restricted in submerged soils to oxidized zones, which include the water column, a small layer of surface soil, and soil in the root zone of aquatic plants. The magnitude of nitrification is regulated by the availability of $\mathrm{O}_{2}$, which determines the fraction of the total soil volume occupied by aerobic zones, and $\mathrm{NH}_{4}^{+}$concentration in these aerobic zones. Ammonium in aerobic zones originates from formation by ammonification within the aerobic zone, inputs of external $\mathrm{N}$ including fertilizer, and diffusion of $\mathrm{NH}_{4}^{+}$from adjacent anaerobic soil zones. $\mathrm{Ni}$ trate formed by nitrification is stable within an aerobic zone, but it can be readily reduced in adjacent anaerobic soil zones. Oxygen availability is typically the factor most limiting nitrification in submerged agricultural soils.

Nitrate does not accumulate in the anaerobic zone because of the high demand for $\mathrm{NO}_{3}^{-}$to serve as an electron acceptor in the absence of $\mathrm{O}_{2}$. Denitrification is the dissimilatory reduction of $\mathrm{NO}_{3}^{-}$, whereby $\mathrm{NO}_{3}^{-}$serves as a terminal electron acceptor and is reduced to gaseous endproducts of nitrous oxide $\left(\mathrm{N}_{2} \mathrm{O}\right)$ and nitrogen gas $\left(\mathrm{N}_{2}\right)$. Denitrification is mediated by heterotrophic microorganisms; and its rate is regulated by $\mathrm{NO}_{3}{ }^{-}$concentration and available $\mathrm{C}$, which serves as an energy source or electron donor. The supply of $\mathrm{NO}_{3}^{-}$originating from the aerobic zones is typically the factor limiting denitrification in submerged soils (Aulakh et al., 2000a).

In submerged soils, the demand for $\mathrm{NO}_{3}^{-}$to serve as an electron acceptor is typically much greater than the demand for $\mathrm{NO}_{3}^{-}$as an $\mathrm{N}$ source for microbes and plants. Assimilatory reduction of $\mathrm{NO}_{3}{ }^{-}$where $\mathrm{NO}_{3}{ }^{-}$is used as a nutrient source and incorporated into cell biomass is consequently not a significant process. Anaerobic soil conditions promote the accumulation of $\mathrm{NH}_{4}^{+}$, which serves as the primary inorganic $\mathrm{N}$ source for microbes and plants. Assimilatory reduction of $\mathrm{NO}_{3}^{-}$ would only be expected when $\mathrm{NH}_{4}^{+}$levels are low and $\mathrm{NO}_{3}^{-}$levels are high.

Dissimilatory reduction of $\mathrm{NO}_{3}^{-}$to $\mathrm{NH}_{4}^{+}$can occur in highly reduced soil (Stanford et al., 1975). This pathway involves transfer of eight electrons for a change in oxidation state of $\mathrm{N}$ from $+5\left(\mathrm{NO}_{3}^{-}\right)$to $-3\left(\mathrm{NH}_{4}^{+}\right)$, whereas denitrification involves transfer of four or five electrons for a change in oxidation state of $\mathrm{N}$ to $+1\left(\mathrm{~N}_{2} \mathrm{O}\right)$ or zero $\left(\mathrm{N}_{2}\right)$. Dissimilatory reduction of $\mathrm{NO}_{3}^{-}$to $\mathrm{NH}_{4}{ }^{+}$is mediated by strict anaerobic microorganisms (Caskey and Tiedje, 1979) and consequently requires the presence of $\mathrm{NO}_{3}^{-}$in a strongly anaerobic soil zone (Buresh and Patrick, 1981). However, it typically represents only a small fraction of the total dissimilatory reduction of $\mathrm{NO}_{3}^{-}$in submerged soils. Nitrate reduction to $\mathrm{NH}_{4}^{+}$for example represented $<5 \%$ of the total reduction of $\mathrm{NO}_{3}^{-}$following the flooding of a rice soil (Buresh et al., 1989). Denitrification is the dominant pathway of dissimilatory $\mathrm{NO}_{3}{ }^{-}$reduction in submerged soils (Patrick, 1982; Aulakh et al., 1992).

A characteristic of submerged soils with important implications for $\mathrm{N}$ cycling is the adjoining presence of aerobic zones where nitrification occurs and anaerobic zones where denitrification occurs. The environments suitable for the growth of nitrifiers and denitrifiers are mutually exclusive, but the transport of substrates and products between the aerobic and anaerobic zones couples nitrification and denitrification. Nitrogen loss by coupled processes of simultaneous nitrification 
and denitrification is consequently a unique feature of submerged soils (Reddy and Patrick, 1986). Nitrate derived through nitrification in an aerobic zone can rapidly diffuse into anaerobic soil layers where it serves as an electron acceptor and is reduced typically to $\mathrm{N}_{2} \mathrm{O}$ and $\mathrm{N}_{2}$. $\mathrm{A} \mathrm{NO}_{3}{ }^{-}$concentration gradient across the aerobic-anaerobic interface resulting from the high demand for electron acceptors and sufficient supply of electron donors (available organic $\mathrm{C}$ ) in anaerobic zones favors the rapid flux of $\mathrm{NO}_{3}^{-}$from aerobic to anaerobic zones (Reddy et al., 1978). Because $\mathrm{NO}_{3}^{-}$is rapidly lost by denitrification, low levels of $\mathrm{NO}_{3}^{-}$in submerged soils do not necessarily reflect low $\mathrm{N}$ loss by nitrification-denitrification.

The addition of fertilizer $\mathrm{N}$, transport of $\mathrm{NH}_{4}^{+}$from anaerobic to aerobic zones, and ammonification in aerobic zones typically supply adequate $\mathrm{NH}_{4}^{+}$for nitrifiers (Patrick and Reddy, 1976). High $\mathrm{NH}_{4}^{+}$levels in aerobic zones suggest the supply of $\mathrm{NH}_{4}^{+}$exceeds the rate at which $\mathrm{NH}_{4}^{+}$is converted to $\mathrm{NO}_{3}^{-}$. The loss of $\mathrm{N}$ by coupled nitrification-denitrification is usually limited by the formation of $\mathrm{NO}_{3}^{-}$(Reddy et al., 1976), and the supply of $\mathrm{NO}_{3}^{-}$can consequently control the size and activity of denitrifiers. The rhizosphere of rice, in addition to the aerobic surface soil layer, is a potentially important site for coupled nitrification-denitrification (Arth et al., 1998; Arth and Frenzel, 2000). The loss of ammonium N through coupled nitrification-denitrification cannot occur in the absence of an aerobic zone.

Before the mid-1980s denitrification was generally considered the main process for $\mathrm{N}$ loss in submerged agricultural soils. The high losses of fertilizer N obtained from ${ }^{15} \mathrm{~N}$ balance studies in submerged rice soils were often attributed to simultaneous nitrification-denitrification at aerobic-anaerobic interfaces near the soil surface, and in the rhizosphere of rice. It is, however, not possible to directly distinguish and quantify the processes responsible for the large portion of added $\mathrm{N}$ typically not accounted for in ${ }^{15} \mathrm{~N}$ balances. The increasing awareness in the $1980 \mathrm{~s}$ of the importance of $\mathrm{NH}_{3}$ loss from fertilizer $\mathrm{N}$ in tropical rice soils heightened the need to directly quantify nitrification-denitrification and determine its importance relative to $\mathrm{NH}_{3}$ volatilization as an $\mathrm{N}$ loss process (Fillery et al., 1986b).

A number of ${ }^{15} \mathrm{~N}$ tracer studies were consequently conducted from the mid1980s in diverse rice fields to directly quantify the evolution of $\mathrm{N}_{2} \mathrm{O}$ and $\mathrm{N}_{2}$ from fertilizer $\mathrm{N}$ applied with a range of methods, times, and rates. These studies typically used urea because of its global importance as an $\mathrm{N}$ source for rice. Directly measured evolution of $\mathrm{N}_{2}$ and $\mathrm{N}_{2} \mathrm{O}$ to the atmosphere represented $\leq 2 \%$ of the urea $\mathrm{N}$ applied to continuously saturated or submerged soils in a series of studies in the Philippines, Indonesia, and Thailand (Buresh and Austin, 1988; John et al., 1989; Buresh et al., 1991; De Datta et al., 1991). Total N loss as determined from unaccounted for $\mathrm{N}$ in ${ }^{15} \mathrm{~N}$ balances in these studies represented 10 to $56 \%$ of the applied urea N. Metal borders surrounding the plots for ${ }^{15} \mathrm{~N}$ balances prevented $\mathrm{N}$ loss by runoff, and leaching was negligible on these puddled soils. The quantity of $\mathrm{N}_{2} \mathrm{O}$ and $\mathrm{N}_{2}$ formed by denitrification but entrapped or dissolved in the soil-floodwater system rather than evolved and included in the measured flux of ${ }^{15} \mathrm{~N}$-labeled $\mathrm{N}_{2} \mathrm{O}$ and $\mathrm{N}_{2}$ was relatively small (Samson et al., 1990). Rice plants can act as a conduit for the transport of $\mathrm{N}$ gases from soil to the overlying atmosphere (Reddy et al., 1989; $\mathrm{Ni}$ and Zhu, 2004), and the evolution of $\mathrm{N}_{2} \mathrm{O}$ and $\mathrm{N}_{2}$ originating from added urea $\mathrm{N}$ is typically greater when gas collection chambers are placed over rather than between rice plants (Mosier et al., 1990; Buresh et al., 1993c; Chen et al., 1998a). However, even when accounting for entrapment of formed $\mathrm{N}_{2} \mathrm{O}$ and $\mathrm{N}_{2}$ and preferential transport of formed $\mathrm{N}_{2} \mathrm{O}$ and $\mathrm{N}_{2}$ through the rice canopy, the con- 
version of applied urea $\mathrm{N}$ to $\mathrm{N}_{2} \mathrm{O}$ and $\mathrm{N}_{2}$ was small in puddled soils that remained saturated or submerged. Therefore, it was concluded that $\mathrm{NH}_{3}$ volatilization and not emission of $\mathrm{N}_{2} \mathrm{O}$ and $\mathrm{N}_{2}$ was the dominant mechanism for loss of applied urea $\mathrm{N}$, representing $>90 \%$ of the lost urea $\mathrm{N}$ in the investigated rice soils (Buresh and De Datta, 1990).

Additional direct measurements of denitrification from submerged rice soils with ${ }^{15} \mathrm{~N}$ tracer techniques confirm relatively small losses of fertilizer $\mathrm{N}$ by nitrification-denitrification as compared with $\mathrm{NH}_{3}$ volatilization. Measured evolution of $\mathrm{N}_{2} \mathrm{O}$ and $\mathrm{N}_{2}$ accounted for $\leq 10 \%$ of the total loss of applied urea $\mathrm{N}$ in a study in India (Mosier et al., 1990), and much less than estimated $\mathrm{NH}_{3}$ loss from applied $\mathrm{NH}_{4}^{+}-\mathrm{N}$ in Australia (Chen et al., 1998a). The findings of Chen et al. (1998a) support the widespread observation that $\mathrm{N}$ loss by denitrification in continuously submerged or saturated rice soil is limited by the rate of nitrification. Directly measured evolution of $\mathrm{N}_{2} \mathrm{O}$ and $\mathrm{N}_{2}$ accounted for $10 \%$ of the applied urea $\mathrm{N}$ in a study in Thailand when crop residue was removed, but no loss of $\mathrm{N}$ as $\mathrm{N}_{2} \mathrm{O}$ and $\mathrm{N}_{2}$ was detected when crop residue was retained, presumably because of immobilization of added N (Phongpan and Mosier, 2003).

Some studies, particularly in the 1980s, indirectly estimated denitrification as the difference between unaccounted for $\mathrm{N}$ in ${ }^{15} \mathrm{~N}$ balances and measured or estimated loss by $\mathrm{NH}_{3}$ volatilization. These estimates of denitrification ranged up to about $50 \%$ of the applied urea $\mathrm{N}$, leading to speculation that $\mathrm{NH}_{3}$ volatilization and denitrification were concurrent, complementary loss mechanisms (De Datta and Buresh, 1989; Freney et al., 1990). In such case the management of urea to reduce $\mathrm{NH}_{3}$ volatilization would lead to concurrent increases in denitrification, resulting in little or no reduction in total loss of fertilizer N. A high variance and uncertainty is, however, associated with indirect estimates of denitrification by difference, and indirectly estimated denitrification rates ranging up to $50 \%$ of the applied urea $\mathrm{N}$ would require much higher nitrification rates than the maximum reported for submerged rice soils (Buresh and De Datta, 1990). An underestimation of $\mathrm{NH}_{3}$ loss, particularly with the simplified bulk aerodynamic method, might have contributed to overestimation of denitrification loss, and high indirect estimates of denitrification have never been substantiated by direct measurements using the ${ }^{15} \mathrm{~N}$ tracer technique.

The reported ineffectiveness of nitrification inhibitors (Simpson et al., 1985) and low reported losses of $\mathrm{N}_{2} \mathrm{O}$ in continuously submerged or saturated rice soils (Bronson et al., 1997b) support the findings of small $\mathrm{N}$ losses by nitrification-denitrification while a soil with relatively low percolation remains submerged. Drainage and reflooding of a soil during rice growth can, however, increase the emission of $\mathrm{N}_{2} \mathrm{O}$ (Bronson et al., 1997b; Chen et al., 1997; Hua et al., 1997) and presumably $\mathrm{N}$ losses by nitrification-denitrification. Some of the emission of $\mathrm{N}_{2} \mathrm{O}$ following soil drainage could, however, arise from the release of dissolved and entrapped $\mathrm{N}_{2} \mathrm{O}$, which was formed before drainage.

Drainage and drying of submerged soils increases the penetration of $\mathrm{O}_{2}$ and the volume of soil pore space filled by air. This can lead to increased nitrification following a lag period for buildup of nitrifiers. The $\mathrm{NO}_{3}^{-}$arising from the increased nitrification can be assimilated by plants and soil microorganisms. Nitrate remaining in soil at the time of reflooding can be rapidly used as an electron acceptor following the depletion of $\mathrm{O}_{2}$ and thereby denitrified to $\mathrm{N}_{2} \mathrm{O}$ and $\mathrm{N}_{2}$. A number of studies have reported enhanced loss of $\mathrm{N}$ with alternate soil drying and 
flooding (Patrick and Wyatt, 1964; Sah and Mikkelsen, 1983; Sharif Zia and Waring, 1987). As a general principle the magnitude of the $\mathrm{N}$ loss depends on the amount of accumulated soil $\mathrm{NO}_{3}^{-}$, which reflects the net effect of supply via nitrification and assimilation by plants.

Buresh et al. (1993a) estimated the nitrification-denitrification loss from urea $\mathrm{N}$ during soil drying and wetting as the increase in unaccounted for $\mathrm{N}$ in ${ }^{15} \mathrm{~N}$ balances for alternate soil drying and wetting as compared with continuous soil submergence. Soil drying for $20 \mathrm{~d}$ from 15 to $35 \mathrm{~d}$ after transplanting during the vegetative growth phase of rice increased unaccounted-for $\mathrm{N}-$ which presumably represented nitrification-denitrification-by 12 to $16 \%$ of the applied urea N. Soil drying for $22 \mathrm{~d}$ from 41 to $63 \mathrm{~d}$ after transplanting during the reproductive phase had no significant effect on unaccounted-for $\mathrm{N}$ indicating the older rice plants effectively assimilated $\mathrm{NO}_{3}^{-}$thereby preventing accumulation of $\mathrm{NO}_{3}^{-}$and subsequent denitrification.

Nitrogen losses by nitrification-denitrification could, however, be relatively higher on porous soils with high rates of water percolation leading to alternate flooding and drainage during cultivation of irrigated rice. Nitrification-denitrification loss on a porous soil in northwestern India was up to $33 \%$ of the applied fertilizer $\mathrm{N}$ as estimated by an acetylene inhibition-intact soil core technique (Aulakh et al., 2001).

Most environments where rice is grown do not have year-round soil submergence and cropping with rice. These soils typically dry between rice crops and become aerobic, which favors nitrification and build up of $\mathrm{NO}_{3}^{-}$(George et al., 1993, 1995; Ladha et al., 1996). The $\mathrm{NO}_{3}^{-}$is denitrified when the soil becomes saturated by rain or irrigation (Buresh and De Datta, 1991). Rain in the fallow period between rice crops stimulates the emission of $\mathrm{N}_{2} \mathrm{O}$ (Bronson et al., 1997c; Abao et al., 2000), which is associated with nitrification-denitrification. Appreciable $\mathrm{NO}_{3}{ }^{-}$can accumulate during the fallow period particularly when periodic rains help maintain a favorable soil water content for nitrification (Buresh et al., 1989). Flooding the aerobic soil in preparation for puddling and land preparation in the Tropics or through flood irrigations before permanent flooding for direct-seeded rice as practiced in Australia and the USA can lead to substantial losses of $\mathrm{NO}_{3}^{-}$by denitrification and a flush in emission of $\mathrm{N}_{2} \mathrm{O}$ (Bacon et al., 1986; Keerthisinghe et al., 1993).

The loss of fertilizer $\mathrm{N}$ by nitrification-denitrification can be reduced by controlling nitrification, which is typically the rate-limiting step in the process leading to $\mathrm{N}$ loss. The buildup of $\mathrm{NO}_{3}^{-}$can be reduced by more effective placement of fertilizer N into the anaerobic zone of soil (Reddy and Patrick, 1977), amendment of fertilizer with a nitrification inhibitor (Keerthisinghe et al., 1996), and use of controlled release fertilizer (Shoji and Kanno, 1994). The reduction in $\mathrm{NO}_{3}^{-}$accumulation with nitrification inhibitors, while effective in controlling $\mathrm{N}$ loss by nitrification-denitrification and leaching, can enhance $\mathrm{NH}_{3}$ volatilization as a result of enhanced buildup of ammoniacal $\mathrm{N}$ in floodwater and surface soil (Mohanty and Mosier, 1990; Chen et al., 1998b).

\section{Anaerobic Ammonium Oxidation}

The majority of the soil profile in wetlands is anaerobic, resulting in accumulation of high levels of $\mathrm{NH}_{4}^{+}$. In the absence of oxygen, it is thermodynamically possible that several other alternate electron acceptors can potentially oxidize $\mathrm{NH}_{4}^{+}-\mathrm{N}$ 
to $\mathrm{N}_{2}$. However, this pathway assumes that some anaerobic bacteria are capable of using $\mathrm{NH}_{4}{ }^{+}-\mathrm{N}$ as an electron donor and derive energy through oxidation. The significance of these processes has been documented for wastewater lagoons and marine sediments (Mulder et al., 1995; Thamdrup and Dalsgaard, 2002; Schmidt et al., 2003). Ammonium oxidation to $\mathrm{N}_{2}$ using nitrite $\left(\mathrm{NO}_{2}^{-}\right)$as an electron acceptor is commonly now known as the "anammox" process (Mulder et al., 1995). The proposed reactions for this process are shown below:

$$
\begin{aligned}
& 5 \mathrm{NH}_{4}^{+}+3 \mathrm{NO}_{3}^{-}=4 \mathrm{~N}_{2}+9 \mathrm{H}_{2} \mathrm{O}+2 \mathrm{H}^{+} \\
& \mathrm{NH}_{4}^{+}+\mathrm{NO}_{2}^{-}=\mathrm{N}_{2}+2 \mathrm{H}_{2} \mathrm{O}
\end{aligned}
$$

At present, this reaction is not reported in submerged agricultural soils, and the significance of the reaction to overall $\mathrm{N}$ loss remains a subject of speculation. The reaction is controlled by availability of $\mathrm{NO}_{2}^{-}$and competition by heterotrophs, which are dominant in submerged soils. Under conditions of limiting available $\mathrm{C}$, it is likely that some autotrophs might use $\mathrm{NH}_{4}^{+}$as an energy source and potentially oxidize it to $\mathrm{N}_{2}$ gas. Submerged soils, however, are typically not limited by $\mathrm{C}$; and when $\mathrm{NO}_{3}{ }^{-}$and $\mathrm{NO}_{2}{ }^{-}$are present in these systems, they will be used by heterotrophic denitrifiers.

\section{Biological Nitrogen Fixation}

Submerged soils are favorable environments for BNF because of their depletion of $\mathrm{O}_{2}$ and ready supply of $\mathrm{C}$ substrate. Nitrogen inputs by BNF help sustain SNSC and maintain SOM, and the input of N by BNF has helped sustain rice yields at low levels without fertilizer $\mathrm{N}$ for hundreds of years on submerged soils. Long-term $\mathrm{N}$ balances for rice grown on submerged soils without fertilizer $\mathrm{N}$ typically indicate the maintenance of total soil $\mathrm{N}$ content, as a result of BNF by associative and free-living microorganisms (App et al., 1984).

Nitrogen fixers - diazotrophs - in submerged agricultural soils can be broadly grouped into indigenous and exogenous systems. The indigenous (autochthonous) BNF system comprises cyanobacteria and phototrophic bacteria inhabiting the floodwater and soil surface, and it comprises heterotrophic bacteria in the root zone and free-living in the soil. These diazotrophs are typically widespread and native in lowland rice ecosystems. The exogenous (allochthonous) BNF system comprises diazotrophs such as $\mathrm{N}_{2}$-fixing cyanobacteria living in symbiosis with Azolla spp. and heterotrophic and phototrophic rhizobia harbored on aquatic legumes. The exogenous system is not ubiquitous in lowland rice ecosystems, and it must be applied or inoculated (Kundu and Ladha, 1995; Ladha and Reddy, 2003).

The diverse autotrophs and heterotrophs comprising the indigenous BNF system occur in soil and floodwater during rice growth and between rice crops when the water regime is favorable. Estimates of indigenous BNF based on $\mathrm{N}$ balances are typically in the range of 15 to $50 \mathrm{~kg} \mathrm{~N} \mathrm{ha}^{-1} \mathrm{crop}^{-1}$ for lowland rice ecosystems with soil submergence. A summary of $211 \mathrm{~N}$ balances compiled from 14 reports of field and pot experiments with rice revealed positive $\mathrm{N}$ balances ranging up to $90 \mathrm{~kg} \mathrm{~N} \mathrm{ha}^{-1} \mathrm{crop}^{-1}$ (Roger and Ladha, 1992). The average positive balance was $24 \mathrm{~kg} \mathrm{~N} \mathrm{ha}^{-1} \mathrm{crop}^{-1}$, and the median was $27 \mathrm{~kg} \mathrm{~N} \mathrm{ha}^{-1} \mathrm{crop}^{-1}$. The mean positive balance was higher in the absence of applied $N\left(30 \mathrm{~kg} \mathrm{~N} \mathrm{ha}^{-1} \mathrm{crop}^{-1}\right)$ than when $\mathrm{N}$ was applied $\left(4 \mathrm{~kg} \mathrm{~N} \mathrm{ha}{ }^{-1} \mathrm{crop}^{-1}\right)$. The $\mathrm{N}$ balances in the absence of applied $\mathrm{N}$, 
when $\mathrm{N}$ losses are small or negligible, presumably approximate $\mathrm{N}$ inputs by the indigenous BNF system (App et al., 1980).

Estimated BNF based on an $\mathrm{N}$ balance during 27 seasons of growing two irrigated rice crops per year without fertilizer $\mathrm{N}$ in the Philippines was $46 \mathrm{~kg} \mathrm{~N} \mathrm{ha}^{-1}$ crop $^{-1}$ (Ladha et al., 2000). This is comparable with the approximate $50 \mathrm{~kg} \mathrm{~N} \mathrm{ha}^{-1}$ crop $^{-1}$ based on $\mathrm{N}$ balance for 2 yr of double rice cropping (Witt et al., 2000b), but higher than the 32 to $41 \mathrm{~kg} \mathrm{~N}$ ha $^{-1} \mathrm{crop}^{-1}$ estimated in an experiment in the Philippines with three continuous crops of rice per year (Cassman et al., 1995). In a more recent examination of four long-term experiments in the Philippines with two or three irrigated rice crops per year, indigenous $\mathrm{BNF}$ as determined by $\mathrm{N}$ balance in plots without fertilizer $\mathrm{N}$, ranged from 19 to $44 \mathrm{~kg} \mathrm{~N} \mathrm{ha}^{-1}$ crop $^{-1}$ during a $15-\mathrm{yr}$ period (Pampolino et al., 2008).

A summary of extensive measurements suggests a mean contribution of about $20 \mathrm{~kg} \mathrm{~N} \mathrm{ha}^{-1} \mathrm{crop}^{-1}$ from free-living cyanobacteria in the absence of fertilizer N (Roger and Ladha, 1992). The growth of free-living cyanobacteria and phototrophic bacteria inhabiting floodwater and the soil surface is limited by low $\mathrm{pH}$, low $\mathrm{P}$, grazer population (Grant et al., 1985), and high ammoniacal N concentration in floodwater (Roger, 1996). Deep placement of early fertilizer $N$ can reduce the inhibitive effect of ammoniacal $\mathrm{N}$ in floodwater on cyanobacteria (Roger et al., 1981).

Associative BNF in the rice rhizosphere occurs mostly during the heading stage when soil inorganic $\mathrm{N}$ is low (Ladha et al., 1988). It depends on rice cultivar and environment (App et al., 1986; Shrestha and Ladha, 1996); and it is often estimated at $<10 \mathrm{~kg} \mathrm{~N} \mathrm{ha}^{-1}$ crop $^{-1}$ although it could theoretically achieve a maximum of $40 \mathrm{~kg} \mathrm{~N}$ ha $^{-1}$ crop $^{-1}$ (Roger and Ladha, 1992). Estimates of BNF by free-living heterotrophic bacteria are typically $<20 \mathrm{~kg} \mathrm{~N} \mathrm{ha}^{-1} \mathrm{crop}^{-1}$ (Roger and Ladha, 1992). The application of straw enhances heterotrophic and photodependent BNF by an estimated 2 to $4 \mathrm{~kg}$ $\mathrm{N} \mathrm{ha}^{-1} \mathrm{Mg}^{-1}$ of applied straw (Santiago-Ventura et al., 1986). The straw serves as a C substrate for heterotrophs, and it can create a more favorable environment for BNF by reducing inorganic $\mathrm{N}$ through temporary immobilization.

A widely studied exogenous BNF system in submerged rice soils is the symbiotic association of the Anabaena azollae Strasburger with the freshwater fern Azolla spp. (Watanabe, 1982; Roger, 1996). The cyanobacterium inhabits the leaf cavity of azolla, which can grow rapidly in submerged soils before the rice crop and during the early growth of rice. Estimates of BNF under field rather than experimental conditions suggest symbiotic BNF from the azolla-cyanobacterium association can contribute 10 to $50 \mathrm{~kg} \mathrm{~N} \mathrm{ha}^{-1} \mathrm{crop}^{-1}$ (Roger and Ladha, 1992).

\section{Ammonium Fixation}

The accumulation of $\mathrm{NH}_{4}^{+}$and the anaerobic conditions following soil submergence are favorable for the temporary fixation of $\mathrm{NH}_{4}^{+}$in soils with high amounts of expandable 2:1 clay minerals (Wen and Cheng, 1997; Schneiders and Scherer, 1998; Zhang and Scherer, 1999, 2000). A buildup of exchangeable $\mathrm{NH}_{4}^{+}$ from mineralization following soil submergence could lead to a concentration gradient favoring $\mathrm{NH}_{4}^{+}$diffusion into the interlayers of clay minerals. Soil submergence can increase $\mathrm{NH}_{4}^{+}$fixation through the reduction and dissolution of $\mathrm{Fe}^{3+}$ oxide coatings on the surface of clay minerals thereby reducing obstacles for $\mathrm{NH}_{4}^{+}$ movement in and out of interlayers of the clay minerals (Scherer and Zhang, 1999). Soil submergence can also increase $\mathrm{NH}_{4}^{+}$fixation through the reduction of octa- 
hedral $\mathrm{Fe}^{3+}$, which increases the negative charge of interlayers of the clay minerals (Scherer and Zhang, 2002). The temporary fixation of $\mathrm{NH}_{4}^{+}$could protect $\mathrm{N}$ from losses, while still enabling a timely release of the $\mathrm{NH}_{4}^{+}$to plants (Keerthisinghe et al., 1984; Schnier et al., 1987a). Nonexchangeable $\mathrm{NH}_{4}^{+}$can be an important source of $\mathrm{N}$ to rice on submerged soils rich in vermiculite (Keerthisinghe et al., 1985).

\section{Leaching}

Leaching is normally not an important process on puddled rice soils with low water infiltration, which represent the majority of rice-growing areas worldwide. The leaching loss of fertilizer $\mathrm{N}$ is often lower during rice cropping on puddled, submerged soils than during the aerobic soil phase in rice-upland crop rotations, such as rice-wheat (Triticum aestivum L.) (Zhu et al., 2000). Even in rice-growing areas without soil puddling, leaching is typically not considered a problem when the management of fertilizer $\mathrm{N}$ is effective (Humphreys et al., 1987a, 1987b). Nitrate that accumulates during the period of soil drying before a rice crop can in some cases be partially lost by leaching after soil is saturated by either rain or irrigation (Becker et al., 2007).

Some rice is grown on porous soils with high infiltration and poor retention of nutrients. One such example is northwestern India where relatively high solar radiation, together with irrigation and nutrient inputs, enables the porous soils to be very productive (Aulakh and Bijay-Singh, 1997). Irrigation and rain can transport urea $\mathrm{N}$ and ammoniacal $\mathrm{N}$ following fertilization into soil where it is more prone to nitrification-denitrification than $\mathrm{NH}_{3}$ volatilization. Low available $\mathrm{C}$ in subsoil can limit denitrification (Aulakh et al., 2000b), leading to accumulation of $\mathrm{NO}_{3}^{-}$below the crop rooting zone. Inefficient management of irrigation water and overuse of fertilizer $\mathrm{N}$ are increasingly recognized as contributing to localized $\mathrm{NO}_{3}{ }^{-}$pollution of groundwater (Bijay-Singh et al., 1995; Bijay-Singh and Yadvinder Singh, 2003). Management of fertilizer $\mathrm{N}$ to better match crop needs and rotation of rice with a deeper rooted crop offer opportunities to reduce $\mathrm{NO}_{3}^{-}$leaching (Aulakh et al., 2000c). Pointplacement of urea below the soil surface is particularly prone to $\mathrm{N}$ loss by leaching on porous soils (Vlek et al., 1980), and deep point-placement of fertilizer $\mathrm{N}$ is consequently not recommended on porous soils (Katyal et al., 1985).

\section{Nitrogen Management in Submerged Soils Nitrogen Fertilizer Management for Rice}

A distinguishing feature of submerged agricultural soils is the low efficiency of fertilizer $\mathrm{N}$ use, arising from the high losses of fertilizer $\mathrm{N}$. Observations from 179 irrigated rice farm sites in six Asian countries in the mid- to late 1990s revealed an average recovery of only $30 \%$ of the applied fertilizer $\mathrm{N}$. The average fertilizer $\mathrm{N}$ use efficiency was an incremental increase of only $11 \mathrm{~kg}$ grain yield kg-1 of applied N (Dobermann et al., 2004). Despite this typically low efficiency of fertilizer $\mathrm{N}$ use in Asian rice fields, rice has considerable capacity to take up fertilizer $\mathrm{N}$ when its application is synchronized with crop demand. Nitrate-containing fertilizers have long been recognized as inappropriate for lowland rice because of the rapid loss of $\mathrm{NO}_{3}^{-}$by denitrification in submerged soils. Urea, because of its high $\mathrm{N}$ analysis, is the main $\mathrm{N}$ fertilizer source for rice worldwide, and much research attention has been devoted to improving its use efficiency for rice. 
Research from the 1970s to early 1990s was instrumental in quantifying the processes and magnitudes of the high fertilizer $\mathrm{N}$ loss. Reducing $\mathrm{N}$ losses understandably received much attention during this period. These efforts particularly focused on the improved placement of urea (Schnier, 1995) and the development of modified $\mathrm{N}$ fertilizer sources less prone to $\mathrm{N}$ loss (Singh and Buresh, 1994). Broadcast application of urea or ammonium-based fertilizer into floodwater of young rice, as often practiced by Asian rice farmers, was discouraged by researchers because of the high $\mathrm{N}$ losses. For puddled soils, researchers advocated the incorporation without standing floodwater of commercially available $\mathrm{N}$ fertilizers before crop establishment (De Datta et al., 1989). For nonpuddled soils, the application of fertilizer $\mathrm{N}$ before permanent flooding was advocated (Bacon et al., 1988).

The point placement of urea or ammonium-based fertilizer has long been recognized as effective in reducing $\mathrm{N}$ loss (Mitsui, 1955; Broadbent and Mikkelsen, 1968). Much effort has been devoted to developing techniques to facilitate deep placement. These techniques included use of a "mud ball" containing urea with soil (De Datta et al., 1968), large granules of urea (Pasandaran et al., 1999), injection of granular urea (Scholten, 1992), and injection of liquid urea (Schnier et al., 1993). The increased labor and cost associated with placement of fertilizer $\mathrm{N}$ into soil has been a constraint to its adoption in the Tropics (Mohanty et al., 1999), although localized adoption of the production and deep placement of urea briquettes for rice is taking place in Bangladesh (Bowen et al., 2005).

Amendment of urea with chemical additives to inhibit biological processes of urea hydrolysis and nitrification and the coating of urea granules to control the rate of $\mathrm{N}$ release have received considerable attention as approaches to reduce fertilizer $\mathrm{N}$ losses. A number of urease inhibitors and controlled release fertilizers have shown an ability to reduce $\mathrm{NH}_{3}$ loss and achieve higher yields with less fertilizer $\mathrm{N}$. The modification of conventional $\mathrm{N}$ fertilizer sources with chemical additives or coatings, however, adds cost to the fertilizer. This added cost must be small relative to the benefit associated with using lower rates of fertilizer $\mathrm{N}$ in order for the modified $\mathrm{N}$ fertilizer sources to be financially attractive (Buresh and Baanante, 1993).

The recognition arising from research in the 1990s of high spatial and temporal variability in SNSC and crop demand for fertilizer N in farmers' fields (Cassman et al., 1996b) created awareness of the need for site-specific $\mathrm{N}$ management enabling dynamic adjustments in $\mathrm{N}$ fertilization to accommodate field-to-field and year-toyear variation in crop requirements for fertilizer N (Doberman and White, 1999). A site-specific nutrient management (SSNM) approach for rice was formulated in which the need for fertilizer $\mathrm{N}$ was determined from the gap between the supply of $\mathrm{N}$ from indigenous sources - as measured with an $\mathrm{N}$ omission plot-and the demand of the rice crop for $\mathrm{N}$ as estimated from the total $\mathrm{N}$ required by the crop to achieve a yield target for average climatic conditions (Witt et al., 1999; Dobermann and Witt, 2004).

The chlorophyll meter provided a quick and nondestructive method for estimating leaf $\mathrm{N}$ content, which is closely related to photosynthetic rate and biomass production and a sensitive indicator of changes in crop $\mathrm{N}$ demand within a growing season (Peng et al., 1993, 1996; Balasubramanian et al., 1999, 2000; Hussain et al., 2000). The relatively high price of the chlorophyll meter, however, limits its use by individual farmers. A simple, nondestructive alternative is to monitor leaf N status with a leaf color chart (LCC) (Furuya, 1987; Balasubramanian et al., 1999, 2003; Bijay-Singh et al., 2002; Shukla et al., 2004). The LCC is typically 
a durable plastic strip about $7 \mathrm{~cm}$ or more wide and about $13 \mathrm{~cm}$ or more long, containing four or more panels that range in color from yellowish green to dark green. Whereas the chlorophyll meter measures light absorption, the LCC is used to monitor leaf greenness and associated leaf $\mathrm{N}$ by visually comparing light reflection from the surface of leaves with the gamut of green-colored panels on the LCC. Several types of LCCs have been developed including ones by Zhejiang Agricultural University (People's Republic of China), the University of California (USA), and the International Rice Research Institute (IRRI) based on a Japanese prototype. Even though the gamut of green colors is visually different among these three LCCs, Yang et al. (2003) reported strong correlations among the scores for the three types of LCCs and direct relationships between chlorophyll meter and LCC readings. In 2003, IRRI in collaboration with the University of California Cooperative Extension (UCCE) developed a new LCC with four colored panels (ranging from yellowish green to dark green) that better matched the reflectance spectra of rice leaves (Witt et al., 2005). The LCC is now widely recommended across Asia for managing the within season applications of fertilizer $\mathrm{N}$ for rice (Buresh, 2007; IRRI, 2007; Witt et al., 2007).

Use of the chlorophyll meter or LCC enables a "real-time" option to N management in which fertilizer $\mathrm{N}$ is applied in congruence with crop need, as determined by leaf color appearance, rather than applied at a prepackaged, uniform rate for large geographical areas (Alam et al., 2005). Measurements with the chlorophyll meter and LCC are typically taken at 7- to 10-d intervals on the most recent fully expanded leaves, beginning at midtillering and continuing to preflowering - when the $\mathrm{N}$ demand by the rice crop is high (Schnier et al., 1987b; Peng and Cassman, 1998). About 20 to $45 \mathrm{~kg} \mathrm{~N} \mathrm{ha}^{-1}$ is then applied whenever the chlorophyll meter or LCC reading falls below a critical threshold. With such real-time $\mathrm{N}$ management, the timing of $\mathrm{N}$ application is not preset and depends on crop $\mathrm{N}$ demand (Peng et al., 1996). The relatively frequent and moderate rates of $\mathrm{N}$ application ensure plant assimilation of a relatively high proportion of the fertilizer $\mathrm{N}$ before it can be lost. The critical threshold values for the chlorophyll meter and LCC can vary among genotypes of rice.

The real-time option for $\mathrm{N}$ management requires periodic observations of the rice crop, which can become less feasible as rice farmers increasingly engage in off-farm employment. Another option referred to as "fixed time-adjustable dose" management of $\mathrm{N}$ involves less frequent crop observations. This option initially used a decision support system (Witt and Dobermann, 2004) to provide-before planting - a pattern for splitting an estimated total fertilizer $\mathrm{N}$ requirement among preset critical growth stages. The predetermined $\mathrm{N}$ doses in the splitting pattern are then dynamically adjusted upward or downward based on either chlorophyll meter of LCC readings at the predetermined times of $\mathrm{N}$ application. Such a fixed time-adjustable-dose option has effectively increased yield and profitability of fertilizer use as compared with existing farmers' practices in intensive irrigated rice ecosystems in Asia (Dobermann et al., 2002, 2004). It has subsequently been refined into a set of guidelines based on rice response to fertilizer $\mathrm{N}$ and a targeted efficiency of fertilizer N use (IRRI, 2007; Witt et al., 2007).

The management of conventional $\mathrm{N}$ fertilizer sources to better match the fieldand time-specific need of the rice crop offers considerable potential for increasing the efficiency of fertilizer $\mathrm{N}$ use for lowland rice in Asia. Approaches for better matching $\mathrm{N}$ fertilization with plant demand for added $\mathrm{N}$ are increasingly high- 
lighting the low $\mathrm{N}$ demand for fertilizer $\mathrm{N}$ before midtillering and the opportunity for Asian rice farmers to increase fertilizer $\mathrm{N}$ use efficiency by reducing early use of fertilizer $\mathrm{N}$ and better matching $\mathrm{N}$ fertilization with crop demand during the period of rapid rice growth (Wang et al., 2001a, 2004, 2007; Hu et al., 2007). The real-time and fixed-time adjustable dose options to $\mathrm{N}$ management were equally effective in increased fertilizer $\mathrm{N}$ use efficiency and yield in multilocation evaluation in China (Buresh et al., 2004), and they are now promoted as two options for improved fertilizer $\mathrm{N}$ management for rice through use of the LCC (Buresh et al., 2005; IRRI, 2007; Witt et al., 2007).

Some fertilizer $\mathrm{N}$ applied in excess of crop demand can be lost as inorganic $\mathrm{N}$ from rice fields and accumulate in groundwater and water bodies (Xing and $\mathrm{Zhu}, 2000)$. The concentration of dissolved inorganic $\mathrm{N}$ in river water in China, for example, has been shown to correlate with annual application of fertilizer $\mathrm{N}$ in its catchment (Duan et al., 2000). The concentration of nitrate in percolating water has also been related to rates of fertilizer $\mathrm{N}$ application (Ma, 1997), and there are increasing reports of nitrate accumulation in groundwater in rice-growing areas with relatively high fertilizer $\mathrm{N}$ rates (Bijay-Singh and Yadvinder Singh, 2003). The management of fertilizer $\mathrm{N}$ to better match the field- and time-specific need of the rice crop offers considerable potential for preventing the buildup and subsequent transport of fertilizer-derived $\mathrm{N}$ into groundwater and water bodies. Nitrogen fertilizer management should ensure that inorganic $\mathrm{N}$ does not accumulate in the soil profile at harvest of rice (Zhu and Chen, 2002).

During the $20 \mathrm{yr}$ from about 1987 to 2007 the focal message for increasing the efficiency of fertilizer $\mathrm{N}$ use for rice has evolved from "reducing $\mathrm{N}$ losses" per se to "feeding crop needs for N" (Buresh, 2007). Varying basal and midseason applications of fertilizer $\mathrm{N}$ to optimally match the field-specific needs of a crop for supplemental $\mathrm{N}$ enhances opportunities for increasing yield per unit of applied fertilizer $\mathrm{N}$ and increasing profit for rice farmers, while also reducing losses of reactive N (Pampolino et al., 2007).

\section{Crop Residue and Green Manure Management}

The retention and incorporation of crop residues in lowland rice fields often has little or no short-term benefits on rice yield (Bijay-Singh et al., 2001; Samra et al., 2003; Thuy et al., 2008), and crop residues are frequently burnt or removed from lowland rice fields. Rice residue with a high $\mathrm{C} / \mathrm{N}$ ratio is a poor-quality source of $\mathrm{N}$ for the subsequent crop. The incorporation of rice residue can have short-term detrimental consequences arising from microbial immobilization of $\mathrm{N}$, leading to temporary decreases in plant-available soil N (Norman et al., 1990).

The plant recovery of rice residue $\mathrm{N}$ is typically low (Table 11-1), although low reported recoveries of ${ }^{15} \mathrm{~N}$ from labeled residues by rice in studies limited to 1 yr might underestimate the role of residue in providing $\mathrm{N}$ to the crop. After four consecutive seasons of incorporating rice straw in California, ${ }^{15} \mathrm{~N}$-labeled residue was incorporated and followed during the subsequent growing season. The recovery by rice of ${ }^{15} \mathrm{~N}$ from labeled residue did not exceed $4 \%$ of the total $\mathrm{N}$ applied, which represented $<2 \mathrm{~kg} \mathrm{~N}$ ha $^{-1}$ (Eagle et al., 2001). Moreover, most of the ${ }^{15} \mathrm{~N}$ was derived from belowground plant sources rather than from the aboveground residue. The total $\mathrm{N}$ accumulation by rice in adjacent microplots not receiving fertilizer $\mathrm{N}$, however, increased by $19 \mathrm{~kg} \mathrm{~N} \mathrm{ha}^{-1}$ after 5 yr of straw incorporation (Eagle 


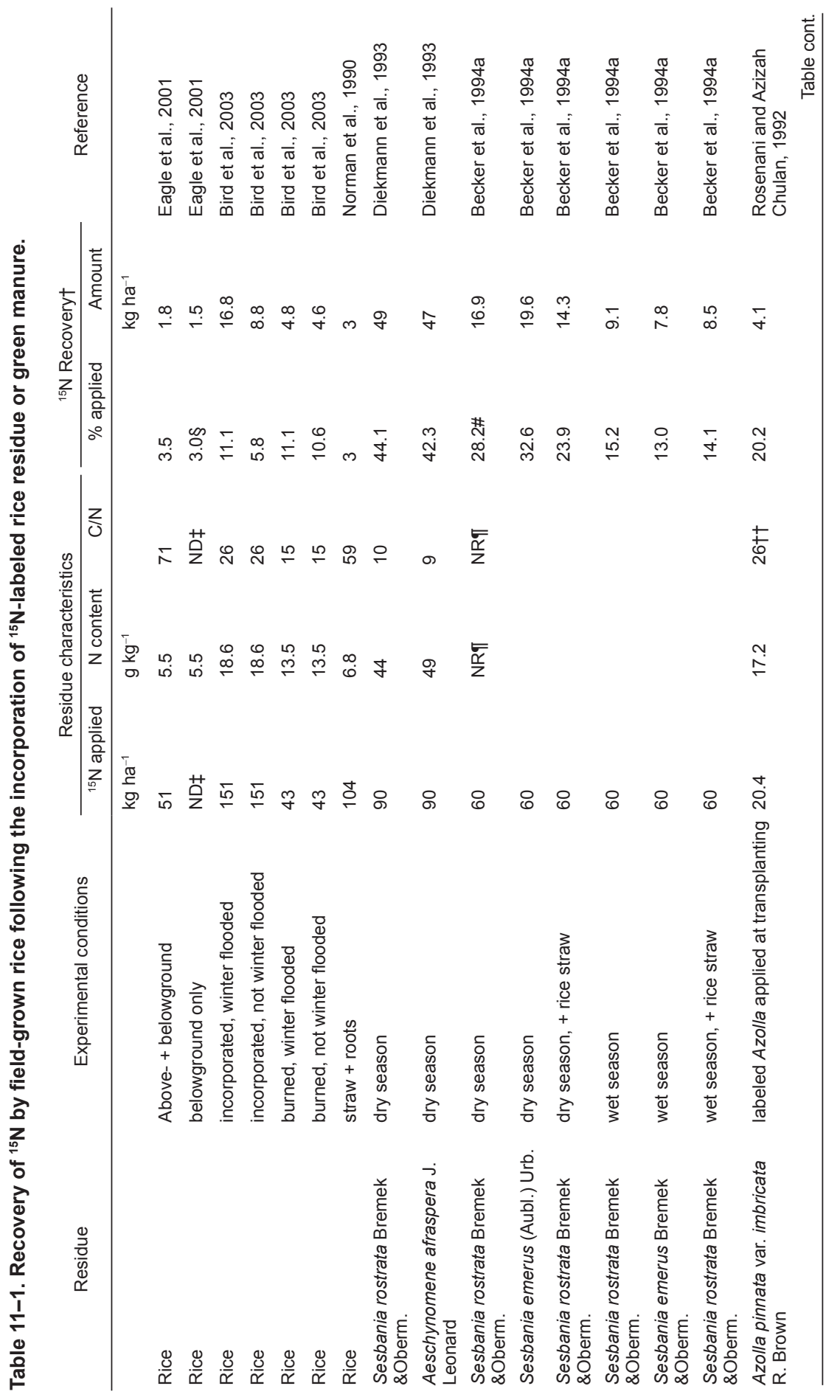




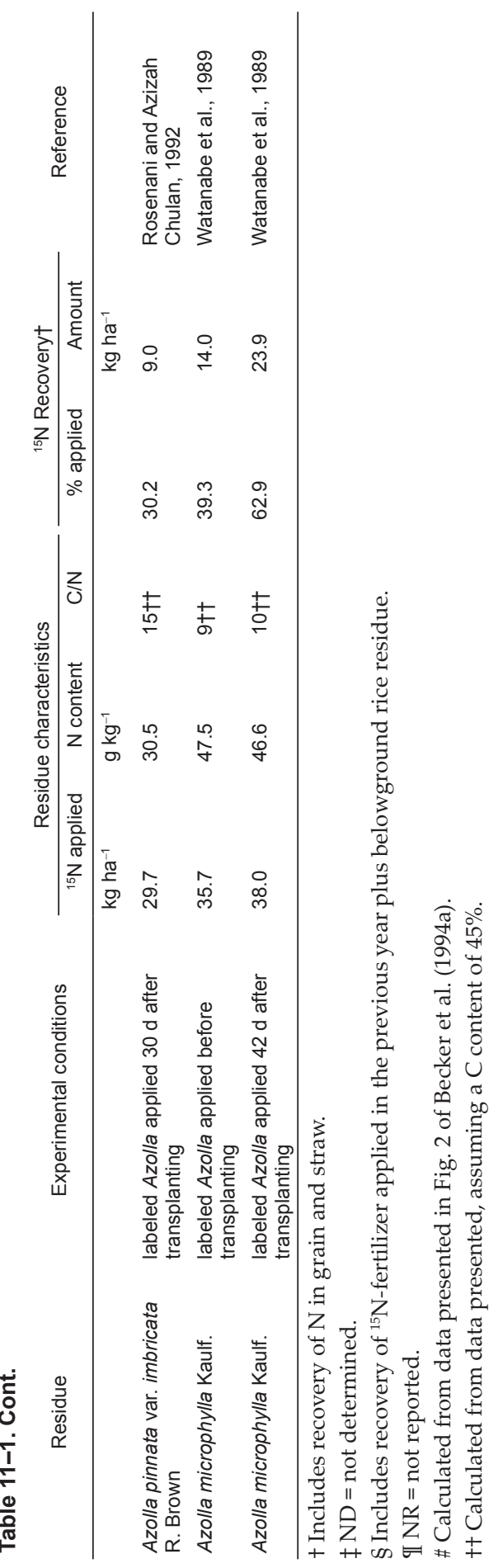


et al., 2000). This suggests that the total recovery of residue $\mathrm{N}$ by rice should not be based only on the 1st year following the application of the residues; but it should consider the cumulative effect over several years.

Several years of straw incorporation are often required before net increases in SNSC and benefits to rice become apparent in the absence of fertilizer N (Verma and Bhagat, 1992; Eagle et al., 2000). Long-term studies indicate increased supply of plant-available soil $\mathrm{N}$ after 5 to $10 \mathrm{yr}$ of rice straw incorporation in Tropics (Cassman et al., 1996a) and temperate areas (Eagle et al., 2000; Bird et al., 2001). Long-term straw incorporation in temperate areas can increase the reservoirs of readily mineralized organic $\mathrm{N}$, suggesting potential after several years for reducing fertilizer $\mathrm{N}$ rates for optimal rice yield (Bird et al., 2001; Eagle et al., 2001; Linquist et al., 2006). Long-term applications of straw, however, do not improve the trends in rice yield in tropical rice systems with two rice crops per year and high inputs of fertilizer $N$ (Dawe et al., 2003). The retention of crop residue is not essential for maintaining soil $\mathrm{C}$ and INS in continuous rice cultivaton with soil submergence. Soil $\mathrm{C}$ was maintained or slightly increased during $15 \mathrm{yr}$ of continuous cultivation with three irrigated rice crops per year and removal of all aboveground crop residues in the Philippines (Pampolino et al., 2008).

In California, the winter flooding of rice fields for 8 to $12 \mathrm{wk}$ provides a wetland habitat for a large number of migratory, foraging waterfowl (Bird et al., 2000). Foraging waterfowl promote soil disturbance leading to a significant increase in residue decomposition (Van Groenigen et al., 2003). The presence of waterfowl, as compared with sites without waterfowl, reduced the residue remaining in the spring by $36 \%$. Grassy weed seed, like rice seed, served as a food source for the foraging waterfowl, and the presence of foraging waterfowl significantly reduced grassy weed (Scirpus mucronatus L.) biomass even when a regular weed control program was followed (Van Groenigen et al., 2003).

Green manures in rice ecosystems are typically legumes or azolla, which have a high growth rate and a high potential to obtain their N from BNF (Kundu and Ladha, 1999; Ladha and Reddy, 2003). Green manures are excellent providers of N to a subsequent rice crop, reducing the need for fertilizer N (Yadvinder-Singh et al., 1991; Becker et al., 1995). Losses of $\mathrm{N}$ from applied green manure are often lower than from urea. Whereas the average loss from urea was $35 \%$ of the applied $\mathrm{N}$, the average loss for green manure was $14 \%$ of the applied $\mathrm{N}$ for $18{ }^{15} \mathrm{~N}$ balance studies (Becker et al., 1995). Losses of $\mathrm{N}$ from green manures can be reduced by better synchronizing the release of $\mathrm{N}$ from the green manure residues with $\mathrm{N}$ assimilation by rice. This can potentially be achieved by mixing green manure residue with other residues, such as rice straw, with high C/N ratio (Becker et al., 1994b).

The application of green manure with urea can reduce $\mathrm{NH}_{3}$ loss from urea. The incorporation of green manure can lead to increased $\mathrm{\rho CO}_{2}$ concentration in floodwater leading to lower $\mathrm{pH}$ of floodwater, thereby reducing $\mathrm{\rho NH}_{3}$ and $\mathrm{NH}_{3}$ loss. Application of green manure can, however, increase $\mathrm{CH}_{4}$ production (De Datta, 1995).

The recovery of $\mathrm{N}$ by rice is typically higher from green manure residues (i.e., Azolla and Sesbania) than from rice residue, which reflects the higher N concentration of green manures (Table 11-1). There is, however, an apparent discrepancy in the amount of $\mathrm{N}$ accumulated by rice from green manures as determined by the ${ }^{15} \mathrm{~N}$ recovery from labeled green manure and by the $\mathrm{N}$ difference approach using unfertilized rice as the control. Whereas the recovery from ${ }^{15} \mathrm{~N}$-labeled green manure did not exceed $20 \mathrm{~kg} \mathrm{~N}$ ha $^{-1}$ (Table 11-1), recoveries by the $\mathrm{N}$ difference ap- 
proach in the same studies were considerably higher (Diekmann et al., 1993; Becker et al., 1994a). This discrepancy in $\mathrm{N}$ recoveries is largely caused by an added $\mathrm{N}$ interaction whereby ${ }^{15} \mathrm{~N}$-labeled residue $\mathrm{N}$ is immobilized by soil microorganisms, which release unlabeled $\mathrm{N}$ that is subsequently accumulated by the crop. The ${ }^{15} \mathrm{~N}$ tracer technique is less appropriate than the $\mathrm{N}$ difference method for determining the total, long-term contribution of $\mathrm{N}$ from green manure and residue to the following crop. On the other hand, ${ }^{15} \mathrm{~N}$-labeled organic $\mathrm{N}$ sources remain an excellent tool to trace the temporal dynamics of $\mathrm{N}$ mineralization and to construct $\mathrm{N}$ recovery budgets for the various plant- and soil-N fractions.

\section{Nitrogen in Lowland Rice-Upland Crop Rotations}

Rice-growing areas in Asia are generally characterized by a wet season in which rice is a well-adapted crop, and a dry season suitable for growth of rice with irrigation or for growth of upland crops on aerated soil. In rotations of lowland rice with an upland crop, the soil is submerged or saturated for most or all of the rice-growing season, but then the soil dries and becomes aerobic when the upland crop is grown. During the period of soil submergence, $\mathrm{NH}_{4}^{+}$is the stable form of inorganic $\mathrm{N}$, which accumulates in the soil. Soil $\mathrm{NO}_{3}^{-}$is normally negligible at the end of the rice-growing season. During the subsequent period of soil aeration, $\mathrm{NO}_{3}{ }^{-}$forms via nitrification of indigenous soil $\mathrm{N}$ and fertilizer $\mathrm{N}$ applied to the upland crop. Accumulated soil $\mathrm{NO}_{3}^{-}$can be rapidly lost by denitrification when soil is flooded and puddled for the next rice crop (Buresh and De Datta, 1991; George et al., 1992; Singh et al., 1999) or when nonpuddled soil is saturated by heavy rains before dry-sown rice takes up accumulated soil $\mathrm{NO}_{3}^{-}$(Sharma et al., 2005). Denitrification losses following soil submergence can match the magnitude of $\mathrm{N}$ losses from fertilizer $\mathrm{N}$ applied to rice, particularly when $\mathrm{NO}_{3}^{-}$formation is much greater than plant demand for $\mathrm{NO}_{3}{ }^{-}$during the aerobic soil phase (Sharma et al., 1985; Buresh et al., 1989).

Green manures and grain legumes, which grow during the phase of aerobic soil conditions, can assimilate soil $\mathrm{NO}_{3}{ }^{-}$and reduce the level of $\mathrm{NO}_{3}{ }^{-}$at the time soil is flooded for rice production (Buresh et al., 1993b; George et al., 1994). The N accumulated in the green manure and grain legume residues that are incorporated during land preparation can supply $\mathrm{N}$ to rice and reduce the need of fertilizer $\mathrm{N}$ (Ladha et al., 1996; Clement et al., 1998; George et al., 1998). Weeds growing during the fallow period between rice crops can also assimilate soil $\mathrm{NO}_{3}^{-}$and recycle the $\mathrm{N}$ through the incorporation of biomass, thereby reducing $\mathrm{N}$ losses and effectively retaining $\mathrm{N}$ within the plant-soil system (Buresh et al., 1989; George et al., 1994).

Excessive application of $\mathrm{N}$ fertilizer to high-valued upland crops can result in large accumulations of soil $\mathrm{NO}_{3}^{-}$before soil submergence for rice (Tripathi et al., 1997). The accumulated $\mathrm{NO}_{3}^{-}$is typically denitrified on flooding and puddling of soils with low infiltration rate and sufficient electron donors for heterotrophic denitrifiers. On porous soils or cracking clay soils, however, the accumulated $\mathrm{NO}_{3}{ }^{-}$can move quickly with irrigation or rainwater into soil zones where insufficient electron donors or insufficient demand for $\mathrm{NO}_{3}{ }^{-}$as an electron acceptor can limit denitrification. Under such cases a sizable portion of the $\mathrm{NO}_{3}^{-}$can leach and eventually accumulate in groundwater (Shrestha and Ladha, 1998). The growth of a crop or green manure without fertilizer $\mathrm{N}$ immediately before the rice crop can capture some 
Table 11-2. Examples of potential denitrification rates in several natural and constructed wetlands.

\begin{tabular}{|c|c|c|c|}
\hline Wetland & Rate & Units & Reference \\
\hline $\begin{array}{l}\text { Wet meadow, Sweden } \\
\text { Sandy soil } \\
\text { Peat soil }\end{array}$ & $\begin{array}{l}6-43 \\
22\end{array}$ & $\begin{array}{l}\mathrm{g} \mathrm{N} \mathrm{m} \mathrm{m}^{-2} \mathrm{yr}^{-1} \\
\mathrm{~g} \mathrm{~N} \mathrm{m^{-2 }} \mathrm{yr}^{-1}\end{array}$ & $\begin{array}{l}\text { Davidsson and } \\
\text { Leonardson, } 1998\end{array}$ \\
\hline Lake edge wetland, New Zealand & $8-9$ & $\mathrm{mg} \mathrm{N} \mathrm{m} \mathrm{m}^{-2} \mathrm{~d}^{-1}$ & Lusby et al., 1998 \\
\hline Forest soil swamp, Louisiana (USA) & 82,232 & $\mathrm{mg} \mathrm{N} \mathrm{m} \mathrm{m}^{-2} \mathrm{~d}^{-1}$ & DeLaune et al., 1998 \\
\hline Mangrove wetland, Thailand & $13-46$ & $\mu$ moles $\mathrm{N} \mathrm{m}^{-2} \mathrm{~d}^{-1}$ & Kristensen et al., 1998 \\
\hline $\begin{array}{l}\text { Treatment wetland marsh, Arcata, California } \\
\text { (USA) }\end{array}$ & $950-1020$ & $\mathrm{mg} \mathrm{N} \mathrm{m}{ }^{-2} \mathrm{~d}^{-1}$ & $\begin{array}{l}\text { Frankenbach and } \\
\text { Meyer, } 1999\end{array}$ \\
\hline Forested treatment wetland, Louisiana (USA) & 100 & $\mathrm{mg} \mathrm{N} \mathrm{m} \mathrm{m}^{-2} \mathrm{~d}^{-1}$ & Blahnik and Day, 2000 \\
\hline $\begin{array}{l}\text { Forest peat soil, Sweden } \\
\text { Sandy loam soil, Sweden }\end{array}$ & $\begin{array}{l}11 \\
2\end{array}$ & $\begin{array}{l}\text { mmoles } \mathrm{N} \mathrm{m}^{-2} \mathrm{~d}^{-1} \\
\text { mmoles } \mathrm{N} \mathrm{m}^{-2} \mathrm{~d}^{-1}\end{array}$ & $\begin{array}{l}\text { Davidsson and Stahl, } \\
2000\end{array}$ \\
\hline $\begin{array}{l}\text { Undisturbed wetlands, New Jersey (USA) } \\
\text { Disturbed wetlands, New Jersey (USA) }\end{array}$ & $\begin{array}{l}<20-260 \\
180-260\end{array}$ & $\begin{array}{l}\mu \text { moles } \mathrm{N} \mathrm{m}^{-2} \mathrm{~h}^{-1} \\
\mu \text { moles } \mathrm{N} \mathrm{m}^{-2} \mathrm{~h}^{-1}\end{array}$ & Seitzinger, 1994 \\
\hline Swamp forest, Minnesota (USA) & $2-8$ & $\mathrm{mg} \mathrm{N} \mathrm{m} \mathrm{m}^{-2} \mathrm{~d}^{-1}$ & Zak and Grigal, 1991 \\
\hline Riparian fen, Denmark & $2-22$ & $\mathrm{mg} \mathrm{N} \mathrm{m}^{-2} \mathrm{yr}^{-1}$ & $\begin{array}{l}\text { Ambus and } \\
\text { Christensen, } 1993\end{array}$ \\
\hline $\begin{array}{l}\text { Red maple swamps, Rhode Island (USA) } \\
\text { Unenriched sites } \\
\text { Enriched sites }\end{array}$ & $\begin{array}{l}0.5-1.6 \\
0.7-3.9\end{array}$ & $\begin{array}{l}\mathrm{gN} \mathrm{m} \mathrm{m}^{-2} \mathrm{yr}^{-1} \\
\mathrm{~g} \mathrm{~N} \mathrm{~m} \mathrm{~m}^{-2} \mathrm{yr}^{-1}\end{array}$ & Hanson et al., 1994 \\
\hline Mesohaline marsh, Virginia (USA) & $1.8-17.6$ & mmoles $\mathrm{N} \mathrm{m}^{-2} \mathrm{~h}^{-1}$ & Tobias et al., 2001 \\
\hline
\end{tabular}

of the accumulated soil $\mathrm{NO}_{3}^{-}$(Agustin et al., 1999), but management to effectively match fertilizer $\mathrm{N}$ use with crop $\mathrm{N}$ demand remains the most effective strategy for preventing $\mathrm{NO}_{3}^{-}$contamination of groundwater (Shrestha and Ladha, 2000).

\section{Nitrogen Loss into Adjacent Wetlands and Streams}

Wetlands and streams are commonly associated with agricultural ecosystems in many landscapes. Wetlands within a watershed function as effective sinks for $\mathrm{NO}_{3}^{-}$discharged from agricultural operations. Along the continuum from uplands to wetlands and adjacent streams, $\mathrm{NO}_{3}^{-}$is rapidly processed through denitrification (Galloway et al., 2003). The efficiency with which riparian wetlands adjacent to streams remove $\mathrm{NO}_{3}^{-}$ from subsurface and surface flow can vary with landscape setting. Devito et al. (2000) showed that the width of vegetated strips might be less important than the depth of permeable riparian sediments, groundwater flow path, and the location of organic-rich subsurface deposits in influencing the ability of riparian zones to remove $\mathrm{NO}_{3}^{-}$. Channelization of rivers destroys riparian wetlands and decreases the water residence time, thus decreasing overall $\mathrm{NO}_{3}{ }^{-}$removal via denitrification (Galloway et al., 2003).

Nitrogen transformation processes in riparian zones and adjacent wetlands are comparable with those in submerged soils, and the efficiency of riparian zones and wetlands to remove $\mathrm{NO}_{3}^{-}$depends on nitrification and denitrification rates. When rates are expressed on a dry soil weight basis, values are typically higher for organic soils with low bulk density as compared with mineral wetland soils with higher bulk density. However, van Hoewyk et al. (2000) noted no significant difference between these two soil types when values were expressed on a soil volume basis. Wetland soils can have a large capacity to process inorganic $\mathrm{N}$ entering from 
agriculture runoff (DeLaune et al., 1998). Selected examples of $\mathrm{N}$ removal through denitrification in wetlands are shown in Table 11-2.

Nitrate removal in a bottomland hardwood swamp increased linearly with loading rates, with rates ranged up to $100 \mathrm{mg} \mathrm{N} \mathrm{m}^{-2} \mathrm{~d}^{-1}$, and nitrification was the primary source of $\mathrm{NO}_{3}^{-}$in this system (Blahnik and Day, 2000). Using isotopic dilution method in a Louisiana swamp forest soil, DeLaune et al. (1998) estimated nitrification rate at $24 \mathrm{mg} \mathrm{N} \mathrm{m}^{-2} \mathrm{~d}^{-1}$, while denitrification rate was $232 \mathrm{mg} \mathrm{N} \mathrm{m}^{-2} \mathrm{~d}^{-1}$. In a lake-edge wetland in New Zealand, Lusby et al. (1998) reported N loss due to coupled nitrification-denitrification as $9 \mathrm{mg} \mathrm{N} \mathrm{m}^{-2} \mathrm{~d}^{-1}$.

Nitrate is usually reduced to $\mathrm{N}_{2^{\prime}}$ and emissions of $\mathrm{N}_{2} \mathrm{O}$ are typically small compared with emissions of $\mathrm{N}_{2}$ (DeLaune et al., 1998). The potential for high $\mathrm{N}_{2} \mathrm{O}$ flux is greater in wetlands with high levels of $\mathrm{NO}_{3}{ }^{-}$and $\mathrm{NO}_{2}^{-}$. Nitrous oxide emissions increased linearly with decrease in water table height of peat wetland (Dowrick et al., 1999). Similarly, raising the water table in forested peatlands caused cessation of $\mathrm{N}_{2} \mathrm{O}$ production (Regina et al., 1999).

\section{References}

Abao, E.B., Jr., K.F. Bronson, R. Wassmann, and U. Singh. 2000. Simultaneous records of methane and nitrous oxide emissions in rice-based cropping systems under rainfed conditions. Nutr. Cycling Agroecosyst. 58:131-139.

Acharya, C.N. 1935a. Studies on the anaerobic decomposition of plant materials. I. The anaerobic decomposition of rice straw (Oryza sativa). Biochem. J. 29:528-541.

Acharya, C.N. 1935b. Studies on the anaerobic decomposition of plant materials. II. Some factors influencing the anaerobic decomposition of rice straw (Oryza sativa). Biochem. J. 29:953-960.

Acharya, C.N. 1935c. Studies on the anaerobic decomposition of plant materials. III. Comparison of the course of decomposition of rice straw under anaerobic, aerobic, and partially aerobic conditions. Biochem. J. 29:1116-1120.

Adhikari, C., K.F. Bronson, G.M. Panuallah, A.P. Regmi, P.K. Saha, A. Dobermann, D.C. Olk, P.R. Hobbs, and E. Pasuquin. 1999. On-farm soil N supply and N nutrition in the ricewheat system of Nepal and Bangladesh. Field Crops Res. 64:273-286.

Agustin, E.O., C.I. Ortal, S.R. Pascua, Jr., P.C. Sta. Cruz, A.T. Padre, W.B. Ventura, S.R. Obien and J.K. Ladha. 1999. Role of indigo in improving the productivity of rainfed lowland rice-based cropping systems. Exp. Agric. 35:201-210.

Alam, M.M., J.K. Ladha, S.R. Khan, Foyjunnessa, H. Rashid, A.H. Khan, and R.J. Buresh. 2005. Leaf color chart for managing nitrogen fertilizer in lowland rice in Bangladesh. Agron. J. 97:949-959.

Ambus, P., and S. Christensen. 1993. Denitrification variability and control in a riparian fen irrigated with agricultural drainage water. Soil Biol. Biochem. 25:915-923.

App, A., T. Santiago, C. Daez, C. Menguito, W. Ventura, A. Tirol, J. Po, I. Watanabe, S.K. De Datta, and P. Roger. 1984. Estimation of the nitrogen balance for irrigated rice and the contribution of phototrophic nitrogen fixation. Field Crops Res. 9:17-27.

App, A.A., I. Watanabe, M. Alexander, W. Ventura, C. Daez, T. Santiago, and S.K. De Datta. 1980. Nonsymbiotic nitrogen fixation associated with the rice plant in flooded soils. Soil Sci. 130:283-289.

App, A.A., I. Watanabe, T.S. Ventura, M. Bravo, and C.D. Jurey. 1986. The effect of cultivated and wild rice varieties on the nitrogen balance of flooded soil. Soil Sci. 141:448-452.

Arth, I., and P. Frenzel. 2000. Nitrification and denitrification in the rhizosphere of rice: The detection of processes by a new multi-channel electrode. Biol. Fertil. Soils 31:427-435.

Arth, I., P. Frenzel, and R. Conrad. 1998. Denitrification coupled to nitrification in the rhizosphere of rice. Soil Biol. Biochem. 30:509-515.

Aulakh, M.S., and Bijay-Singh. 1997. Nitrogen losses and fertilizer N use efficiency in irrigated porous soils. Nutr. Cycl. Agroecosyst. 47:197-212.

Aulakh, M.S., J.W. Doran, and A.R. Mosier. 1992. Soil denitrification-significance, measurement, and effects of management. Adv. Soil Sci. 18:1-57. 
Aulakh, M.S., T.S. Khera, and J.W. Doran. 2000a. Mineralization and denitrification in upland, nearly saturated and flooded subtropical soil. I. Effect of nitrate and ammoniacal nitrogen. Biol. Fertil. Soils 31:162-167.

Aulakh, M.S., T.S. Khera, and J.W. Doran. 2000b. Mineralization and denitrification in upland, nearly saturated and flooded subtropical soil. II. Effect of organic manures varying in $\mathrm{N}$ content and C:N ratio. Biol. Fertil. Soils 31:168-174.

Aulakh, M.S., T.S. Khera, J.W. Doran, and K.F. Bronson. 2001. Denitrification, $\mathrm{N}_{2} \mathrm{O}$ and $\mathrm{CO}_{2}$ fluxes in rice-wheat cropping system as affected by crop residues, fertilizer $\mathrm{N}$ and legume green manure. Biol. Fertil. Soils 34:375-389.

Aulakh, M.S., T.S. Khera, J.W. Doran, Kuldip-Singh, and Bijay-Singh. 2000c.Yields and nitrogen dynamics in a rice-wheat system using green manure and inorganic fertilizer. Soil Sci. Soc. Am. J. 64:1867-1876.

Bacon, P.E., E.H. Hoult, L.G. Lewin, and J.W. McGarity. 1988. Ammonia volatilization from drill sown rice bays. Fertil. Res. 16:257-272.

Bacon, P.E., J.W. McGarity, E.H. Hoult, and D. Alter. 1986. Soil mineral nitrogen concentration within cycles of flood irrigation: Effect of rice stubble and fertilization management. Soil Biol. Biochem. 18:173-178.

Balasubramanian, V., J.K. Ladha, R.K. Gupta, R.K. Naresh, and R.S. Mehla. Bijay-Singh, and Yadvinder-Singh. 2003. Technology options for rice in the rice-wheat system in south Asia. p. 115-147. In J.K. Ladha et al. (ed.) Improving the productivity and sustainability of rice-wheat systems: Issues and impacts. ASA Spec. Publ. 65. ASA, CSSA, and SSSA, Madison, WI.

Balasubramanian, V., A.C. Morales, R.T. Cruz, and S. Abdulrachman. 1999. On-farm adaptation of knowledge-intensive nitrogen management technologies for rice systems. Nutr. Cycling Agroecosyst. 53:59-69.

Balasubramanian, V., A.C. Morales, R.T. Cruz, T.M. Thiyagarajan, R. Nagarajan, M. Babu, S. Abdulrachman, and L.H. Hai. 2000. Adaptation of the chlorophyll meter (SPAD) technology for real-time N management in rice: A review. Int. Rice Res. Notes 25:4-8.

Bao Ve, N., D.C. Olk, and K.G. Cassman. 2004a. Characterization of humic acid fractions improves estimates of nitrogen mineralization kinetics for lowland rice soils. Soil Sci. Soc. Am. J. 68:1266-1277.

Bao Ve, N., D.C. Olk, and K.G. Cassman. 2004b. Nitrogen mineralization from humic acid fractions in rice soils depends on degree of humification. Soil Sci. Soc. Am. J. 68:1278-1284.

Becker, M., F. Asch, S.L. Maskey, K.R. Pande, S.C. Shah, and S. Shrestha. 2007. Effects of transition season management of soil $\mathrm{N}$ dynamics and system $\mathrm{N}$ balances in rice-wheat rotations of Nepal. Field Crops Res. 103:98-108.

Becker, M., J.K. Ladha, and M. Ali. 1995. Green manure technology: Potential, usage, and limitation. A case study for lowland rice. Plant Soil 174:181-194.

Becker, M., J.K. Ladha, and J.C.G. Ottow. 1994a. Nitrogen losses and lowland rice yield as affected by residue nitrogen release. Soil Sci. Soc. Am. J. 58:1660-1665.

Becker, M., J.K. Ladha, I.C. Simpson, and J.C.G. Ottow. 1994b. Parameters affecting residue nitrogen mineralization in flooded soils. Soil Sci. Soc. Am. J. 58:1666-1671.

Bijay-Singh, K.F. Bronson, Yadvinder-Singh, T.S. Khera, and E. Pasuquin. 2001. Nitrogen-15 balance as affected by rice straw management in a rice-wheat rotation in northwest India. Nutr. Cycl. Agroecosyst. 59:227-237.

Bijay-Singh, and Yadvinder-Singh. 2003. Environmental implications of nutrient use and crop management in rice-based ecosystems. p. 463-477. In T.W. Mew et al. (ed.) Rice science: Innovations and impact for livelihood. Proc. Int. Rice Res. Conf., Beijing, People's Repub. of China.16-19 Sept. 2002. IRRI, Chinese Acad. Eng., and Chinese Acad. Agric. Sci., Beijing, People's Repub. of China.

Bijay-Singh, Y. Singh, J.K. Ladha, K.F. Bronson, V. Balasubramanian, J. Singh, and C.S. Khind. 2002. Chlorophyll meter- and leaf color chart-based nitrogen management for rice and wheat in northwestern India. Agron. J. 94:821-829.

Bijay-Singh, Yadvinder-Singh, and G.S. Sekhon. 1995. Fertilizer use efficiency and nitrate pollution of groundwater in developing countries. J. Contam. Hydrol. 20:167-184.

Bird, J.A., W.R. Horwath, A.J. Eagle, and C. van Kessel. 2001. Immobilization of fertilizer nitrogen in rice: Effects of straw management practices. Soil Sci. Soc. Am. J. 65:1143-1152.

Bird, J.A., G.S. Pettygrove, and J.M. Eadie. 2000. The impact of waterfowl foraging on the decomposition of rice straw: Mutual benefits for rice growers and waterfowl. J. Appl. Ecol. 37:728-741. 
Bird, J.A., C. van Kessel, and W.R. Horwath. 2002. Nitrogen dynamics in humic fractions under alternative straw management in temperate rice. Soil Sci. Soc. Am. J. 66:478-488.

Bird, J.A., C. van Kessel, and W.R. Horwath. 2003. Stabilization of ${ }^{13} \mathrm{C}$-carbon and immobilization of ${ }^{15} \mathrm{~N}$-nitrogen from rice straw in humic fractions. Soil Sci. Soc. Am. J. 67:806-816.

Blahnik, T., and J. Day. 2000. The effects of varied hydraulic and nutrient loading rates on water quality and hydrologic distributions in a natural forested treatment wetland. Wetlands 20:48-61.

Bouldin, D.R., and B. Alimagno. 1976. $\mathrm{NH}_{3}$ volatilization losses from IRRI paddies following broadcast applications of fertilizer nitrogen. IRRI Int. Rep. IRRI, Los Baños, Philippines.

Bowen, W.T., R.B. Diamond, U. Singh, and T.P. Thompson. 2005. Urea deep placement increases yield and saves nitrogen fertilizer in farmers' fields in Bangladesh. p. 369-372. In K. Toriyama et al. (ed.) Rice is life: Scientific perspectives for the 21st century. Proc. World Rice Res. Conf., Tsukuba, Japan. 5-7 Nov 2004. IRRI, Los Baños, Philippines, and JIRCAS, Tsukuba, Japan.

Broadbent, F.E., and D.S. Mikkelsen. 1968. Influence of placement on uptake of tagged nitrogen by rice. Agron. J. 60:674-677.

Bronson, K.F., K.G. Cassman, R. Wassmann, D.C. Olk, M. van Noordwijk, and D.P. Garrity. 1997a. Soil carbon dynamics in different cropping systems in principal ecoregions of Asia. p. 35-57. In R. Lal et al. (ed.) Management of carbon sequestration in soil. CRC Press, Boca Raton, FL.

Bronson, K.F., H.-U. Neue, U. Singh, and E.B. Abao, Jr. 1997b. Automated chamber measurements of methane and nitrous oxide flux in a flooded rice soil: I. Residue, nitrogen, and water management. Soil Sci. Soc. Am. J. 61:981-987.

Bronson, K.F., U. Singh, H.-U. Neue, and E.B. Abao, Jr. 1997c. Automated chamber measurements of methane and nitrous oxide flux in a flooded rice soil: II. Fallow period emissions. Soil Sci. Soc. Am. J. 61:988-993.

Buresh, R.J. 2007. Fertile progress. Rice Today 6(3):32-33.

Buresh, R.J., and E.R. Austin. 1988. Direct measurement of dinitrogen and nitrous oxide flux in flooded rice fields. Soil Sci. Soc. Am. J. 52:681-688.

Buresh, R.J., and C.A. Baanante. 1993. Potential economic benefits of modifications to urea that increase yield through reduction in nitrogen losses. Agron. J. 85:947-954.

Buresh, R.J., E.G. Castillo, and S.K. De Datta. 1993a. Nitrogen losses in puddled soils as affected by timing of water deficit and nitrogen fertilization. Plant Soil 157:197-206.

Buresh, R.J., T.T. Chua, E.G. Castillo, S.P. Liboon, and D.P. Garrity. 1993b. Fallow and sesbania effects on soil nitrogen dynamics in lowland rice-based cropping systems. Agron. J. 85:316-321.

Buresh, R.J., and S.K. De Datta. 1990. Denitrification losses from puddled rice soils in the tropics. Biol. Fertil. Soils 9:1-13.

Buresh, R.J., and S.K. De Datta. 1991. Nitrogen dynamics and management in rice-legume cropping systems. Adv. Agron. 45:1-59.

Buresh, R.J., S.K. De Datta, J.L. Padilla, and T.T. Chua. 1988a. Potential of inhibitors for increasing response of lowland rice to urea fertilization. Agron. J. 80:947-952.

Buresh, R.J., S.K. De Datta, J.L. Padilla, and M.I. Samson. 1988b. Field evaluation of two urease inhibitors with transplanted lowland rice. Agron. J. 80:763-768.

Buresh, R.J., S.K. De Datta, M.I. Samson, S. Phongpan, P. Snitwongse, A.M. Fagi, and R. Tejasarwana. 1991. Dinitrogen and nitrous oxide flux from urea basally applied to puddled rice soils. Soil Sci. Soc. Am. J. 55:268-273.

Buresh, R.J., and W.H. Patrick, Jr. 1981. Nitrate reduction to ammonium and organic nitrogen in an estuarine sediment. Soil Biol. Biochem. 13:279-283.

Buresh, R., S. Peng, J. Huang, J. Yang, G. Wang, X. Zhong, and Y. Zou. 2004. Rice systems in China with high nitrogen inputs. p. 143-153. In A.R. Mosier et al. (ed.) Agriculture and the nitrogen cycle: Assessing the impacts of fertilizer use on food production and the environment. Island Press, Washington, D.C.

Buresh, R.J., M.I. Samson, and S.K. De Datta. 1993c. Quantification of denitrification in flooded soils as affected by rice establishment method. Soil Biol. Biochem. 25:843-848.

Buresh, R.J., C. Witt, S. Ramanathan, B. Chandrasekaran, and R. Rajendran. 2005. Site-specific nutrient management: Managing N, P, and K for rice. Fertil. News 50 (3):25-28, 31-37.

Buresh, R.J., T. Woodhead, K.D. Shepherd, E. Flordelis, and R.C. Cabangon. 1989. Nitrate accumulation and loss in a mungbean/lowland rice cropping system. Soil Sci. Soc. Am. J. 53:477-482. 
Byrnes, B.H., and A. Amberger. 1989. Fate of broadcast urea in a flooded soil when treated with N-(n-butyl) thiophosphoric triamide, a urease inhibitor. Fertil. Res. 18:221-231.

Cai, G.X. 1997. Ammonia volatilization. p. 193-213. In Z.L. Zhu et al. (ed.) Nitrogen in soils of China. Kluwer Academic Publ., Dordrecht, The Netherlands.

Cai, G.X., D.L. Chen, H. Ding, A. Pacholski, X.H. Fan, and Z.L. Zhu. 2002. Nitrogen losses from fertilizers applied to maize, wheat, and rice in the North China Plain. Nutr. Cycling Agroecosyst. 63:187-195.

Cai, G.X., J.R. Freney, E. Humphreys, O.T. Denmead, M. Samson, and J.R. Simpson. 1987. Use of surface films to reduce ammonia volatilization from flooded rice fields. Aust. J. Agric. Res. 39:177-186.

Cao, Z.H., S.K. De Datta, and I.R.P. Fillery. 1983. Effect of placement methods on floodwater properties and recovery of applied N ( ${ }^{15} \mathrm{~N}$-labeled urea) in wetland rice. Soil Sci. Soc. Am. J. 48:196-203.

Caskey, W.H., and J.M. Tiedje. 1979. Evidence for clostridia as agents of dissimilatory reduction of nitrate to ammonium in soils. Soil Sci. Soc. Am. J. 43:931-936.

Cassman, K.G., S.K. De Datta, S.T. Amarante, S.P. Liboon, M.I. Samson, and M.A. Dizon. 1996a. Long-term comparison of the agronomic efficiency and residual benefits of organic and inorganic nitrogen sources for tropical lowland rice. Exp. Agric. 32:427-444.

Cassman, K.G., S.K. De Datta, D.C. Olk, J. Alcantara, M. Samson, J. Descalsota, and M. Dizon. 1995. Yield decline and the nitrogen economy of long-term experiments on continuous, irrigated rice systems in the tropics. p. 181-222. In R. Lal and B.A. Stewart (ed.) Soil management: Experimental basis for sustainability and environmental quality. CRC Press, Boca Raton, FL.

Cassman, K.G., A. Dobermann, P.C.S. Cruz, G.C. Gines, M.I. Samson, J.P. Descalsota, J.M. Alcantara, M.A. Dizon, and D.C. Olk. 1996b. Soil organic matter and the indigenous nitrogen supply of intensive irrigated rice systems in the tropics. Plant Soil 182:267-278.

Cassman, K.G., G.C. Gines, M.A. Dizon, M.I. Samson, and J.M. Alcantara. 1996c. Nitrogenuse efficiency in tropical lowland rice systems: Contributions from indigenous and applied nitrogen. Field Crops Res. 47:1-12.

Cassman, K.G., S. Peng, D.C. Olk, J.K. Ladha, W. Reichardt, A. Dobermann, and U. Singh.1998. Opportunities for increased nitrogen-use efficiency from improved resource management in irrigated rice systems. Field Crop Res. 56:7-39.

Chaiwanakupt, P., J.R. Freney, R. Keerthisinghe, S. Phongpan, and R.L. Blakeley. 1996. Use of urease, algal inhibitors, and nitrification inhibitors to reduce nitrogen loss and increase the grain yield of flooded rice (Oryza sativa L.). Biol. Fertil. Soils 22:89-95.

Chen, D.L., P.M. Chalk, and J.R. Freney. 1998a. Nitrogen transformations in a flooded soil in the presence and absence of rice plants: II. Denitrification. Nutr. Cycl. Agroecosyst. 51:269-279.

Chen, D.L., P.M. Chalk, J.R. Freney, and Q.X. Luo. 1998b. Nitrogen transformations in a flooded soil in the presence and absence of rice plants: 1. Nitrification. Nutr. Cycl. Agroecosyst. 51:259-267.

Chen, G.X., G.H. Huang, B. Huang, K.W. Yu, J. Wu, and H. Xu. 1997. Nitrous oxide and methane emissions from soil-plant systems. Nutr. Cycling Agroecosyst. 49:41-45.

Cisse, M., and P.L.G. Vlek. 2003a. Conservation of urea-N by immobilization-remobilization in a rice-Azolla intercrop. Plant Soil 250:95-104.

Cisse, M., and P.L.G. Vlek. 2003b. Influence of urea on biological $\mathrm{N}_{2}$ fixation and $\mathrm{N}$ transfer from Azolla intercropped with rice. Plant Soil 250:105-112.

Clement, A., J.K. Ladha, and F.-P. Chalifour. 1998. Nitrogen dynamics of various green manure species and the relationship to lowland rice production. Agron. J. 90:149-154.

Davidsson, T.E., and L. Leonardson. 1998. Seasonal dynamics of denitrification activity in two water meadows. Hydrobiologia 364:189-198.

Davidsson, T.E., and M. Stahl. 2000. The influence of organic carbon on nitrogen transformations in five wetland soils. Soil Sci. Soc. Am. J. 64:1129-1136.

Dawe, D., A. Dobermann, J.K. Ladha, R.L. Yadav, Lin Bao, R.K. Gupta, P. Lal, G. Panaullah, O. Sariam, Y. Singh, A. Swarup, and Q.-X. Zhen. 2003. Do organic amendments improve yield trends and profitability in intensive rice systems? Field Crops Res. 83:191-213.

De Datta, S.K. 1995. Nitrogen transformations in wetland rice ecosystems. Fertil. Res. 42:193-203.

De Datta, S.K., and R.J. Buresh. 1989. Integrated nitrogen management in irrigated rice. Adv. Soil Sci. 10:143-169. 
De Datta, S.K., R.J. Buresh, M.I. Samson, W.N. Obcemea, and J.G. Real. 1991. Direct measurement of ammonia and denitrification fluxes from urea applied to rice. Soil Sci. Soc. Am. J. 55:543-548.

De Datta, S.K., I.R.P. Fillery, W.N. Obcemea, and R.C. Evangelista. 1987a. Floodwater properties, nitrogen utilization, and nitrogen-15 balance in a calcareous lowland rice soil. Soil Sci. Soc. Am. J. 51:1355-1362.

De Datta, S.K., C.P. Magnaye, and J.C. Moomaw. 1968. Efficiency of fertilizer nitrogen $\left({ }^{15} \mathrm{~N}-\right.$ labelled) for flooded rice. p. 67-76. In Trans. 9th Int. Congr. Soil Sci., Vol. 4, Adelaide, Australia.

De Datta, S.K., W.N. Obcemea, R.Y. Chen, J.C. Calabio, and R.C. Evangelista. 1987b. Effect of water depth on nitrogen use efficiency and nitrogen-15 balance in lowland rice. Agron J. 79:210-216.

De Datta, S.K., A.C.F. Trevitt, J.R. Freney, W.N. Obcemea, J.G. Real, and J.R. Simpson. 1989. Measuring nitrogen losses from lowland rice using bulk aerodynamic and nitrogen-15 balance methods. Soil Sci. Soc. Am. J. 53:1275-1281.

DeLaune, R.D., C.W. Lindau, E. Sulaeman, and A. Jugsujinda. 1998. Nitrification and denitrification estimates in a Louisiana swamp forest soil as assessed by N-15 isotope dilution and direct gaseous measurements. Water Air Soil Pollut. 106:149-161.

DeLaune, R.D., W.H. Patrick, Jr., and R.J. Buresh. 1979. Effect of crude oil on a Louisiana Spartina alterniflora salt marsh. Environ. Pollut. 20:21-31.

de Macale, M.A.R., and P.L.G. Vlek. 2004. The role of Azolla cover in improving the nitrogen use efficiency of lowland rice. Plant Soil 263:311-321.

Denmead, O.T., J.R. Freney, and J.R. Simpson. 1982. Dynamics of ammonia volatilization during furrow irrigation of maize. Soil Sci. Soc. Am. J. 46:149-155.

Devasenapathy, P., and S.P. Palaniappan. 1996. Increasing urea-N efficiency in transplanted lowland rice by urea solution band placement. Biol. Fertil. Soils 22:283-286.

Devito, K.J., D. Fitzgerald, A.R. Hill, and R. Aravena. 2000. Nitrate dynamics in relation to lithology and hydrologic flow path in a river riparian zone. J. Environ. Qual. 29:1075-1084.

Diekmann, K.H., S.K. De Datta, and J.C.G. Ottow. 1993. Nitrogen uptake and recovery from urea and green manure in lowland rice measured by ${ }^{15} \mathrm{~N}$ and non-isotope techniques. Plant Soil 148:91-99.

Dobermann, A., S. Abdulrachman, H.C. Gines, R. Nagarajan, S. Satawathananont, T.T. Son, P.S. Tan, G.H. Wang, G.C. Simbahan, M.A.A. Adviento, and C. Witt. 2004. Agronomic performance of site-specific nutrient management in intensive rice-cropping systems of Asia. p. 307-336. In A. Dobermann et al. (ed.) Increasing productivity of intensive rice systems through site-specific nutrient management. Scientific Publ., Enfeld, NH (USA) and IRRI, Los Baños, Philippines.

Dobermann, A., and P.F. White. 1999. Strategies for nutrient management in irrigated and rainfed lowland rice systems. Nutr. Cycling Agroecosyst. 53:1-18.

Dobermann, A., and C. Witt. 2004. The evolution of site-specific nutrient management in irrigated rice systems of Asia. p. 75-99. In A. Dobermann et al. (ed.) Increasing productivity of intensive rice systems through site-specific nutrient management. Scientific Publ. Enfeld, NH (USA) and IRRI, Los Baños, Philippines.

Dobermann, A., C. Witt, S. Abdulrachman, H.C. Gines, R. Nagarajan, T.T. Son, P.S. Tan, G.H. Wang, N.V. Chien, V.T.K. Thoa, C.V. Phung, P. Stalin, P. Muthukrishnan, V. Ravi, M. Babu, G.C. Simbahan, and M.A.A. Adviento. 2003. Soil fertility and indigenous nutrient supply in irrigated rice domains of Asia. Agron. J. 95:913-923.

Dobermann, A., C. Witt, D. Dawe, S. Abdulrachman, H.C. Gines, R. Nagarajan, S. Satawathananont, T.T. Son, P.S. Tan, G.H. Wang, N.V. Chien, V.T.K. Thoa, C.V. Phung, P. Stalin, P. Muthukrishnan, V. Ravi, M. Babu, S. Chatuporn, J. Sookthongsa, Q. Sun, R. $\mathrm{Fu}$, G.C. Simbahan, and M.A.A. Adviento. 2002. Site-specific nutrient management for intensive rice cropping systems in Asia. Field Crops Res. 74:37-66.

Dolmat, M.T., W.H. Patrick, Jr., and F.J. Peterson. 1980. Relation of available soil nitrogen to rice yield. Soil Sci. 129:229-237.

Dowrick, D.J., S. Hughes, C. Freeman, M.A. Lock, B. Reynolds, and J.A. Hudson. 1999. Nitrous oxide emissions from a gully mire in mid-Wales, UK, under simulated summer drought. Biogeochemistry 44:151-162.

Duan, S., S. Zhang, and H. Huang. 2000. Transport of dissolved inorganic nitrogen from the major rivers to estuaries in China. Nutr. Cycling Agroecosyst. 57:13-22.

Eagle, A.J., J.A. Bird, J.E. Hill, W.R. Horwath, and C. van Kessel. 2001. Nitrogen dynamics and fertilizer use efficiency in rice following straw incorporation and winter flooding. Agron. J. 93:1346-1354. 
Eagle, A.J., J.A. Bird, W.R. Horwath, B.A. Linquist, S.M. Brouder, J.E. Hill, and C. van Kessel. 2000. Rice yield and nitrogen utilization efficiency under alternative straw management practices. Agron. J. 92:1096-1103.

Fillery, I.R.P., and S.K. De Datta. 1986. Ammonia volatilization from nitrogen sources applied to rice fields: I. Methodology, ammonia fluxes, and nitrogen-15 loss. Soil Sci. Soc. Am. J. 50:80-86.

Fillery, I.R.P., P.A. Roger, and S.K. De Datta. 1986a. Ammonia volatilization from nitrogen sources applied to rice fields: II. Floodwater properties and submerged photosynthetic biomass. Soil Sci. Soc. Am. J. 50:86-91.

Fillery, I.R.P., J.R. Simpson, and S.K. De Datta. 1984. Influence of field environment and fertilizer management on ammonia loss from flooded rice. Soil Sci. Soc. Am. J. 48:914-920.

Fillery, I.R.P., J.R. Simpson, and S.K. De Datta. 1986b. Contribution of ammonia volatilization to total nitrogen loss after applications of urea to wetland rice fields. Fertil. Res. 8:193-202.

Frankenbach, R.I., and J.S. Meyer. 1999. Nitrogen removal in a surface-flow wastewater treatment wetland. Wetlands 19:403-412.

Freney, J.R. 1997. Strategies to reduce gaseous emissions of nitrogen from irrigated agriculture. Nutr. Cycling Agroecosyst. 48:155-160.

Freney, J.R., O.T. Denmead, I. Watanabe, and E.T. Craswell. 1981. Ammonia and nitrous oxide losses following applications of ammonium sulfate to flooded rice. Aust. J. Agric. Res. 32:37-45.

Freney, J.R., R. Leuning, J.R. Simpson, O.T. Denmead, and W.A. Muirhead. 1985. Estimating ammonia volatilization from flooded rice fields by simplified techniques. Soil Sci. Soc Am. J. 49:1049-1054

Freney, J.R., A.C.F. Trevitt, S.K. De Datta, W.N. Obcemea, and J.G. Real. 1990. The interdependence of ammonia volatilization and denitrification as nitrogen loss processes in flooded rice fields in the Philippines. Biol. Fertil. Soils 9:31-36.

Fujisaka, S. 1994. Were farmers wrong in rejecting a recommendation? The case of nitrogen at transplanting for irrigated rice. Agric. Syst. 43:271-286.

Furuya, S. 1987. Growth diagnosis of rice plants by means of leaf color. Jpn. Agric. Res. Q. 20:147-153.

Galloway, J.N., J.D. Aber, J.W. Erisman, S.P. Seitzinger, R.W. Howarth, E.B. Cowling, and B.J. Cosby. 2003. The nitrogen cascade. Bioscience 53:341-356.

George, T., R.J. Buresh, J.K. Ladha, and G. Punzalan. 1998. Recycling in situ of legume-fixed and soil nitrogen in tropical lowland rice. Agron. J. 90:429-437.

George, T., J.K. Ladha, R.J. Buresh, and D.P. Garrity. 1992. Managing native and legume-fixed nitrogen in lowland rice-based cropping systems. Plant Soil 141:69-91.

George, T., J.K. Ladha, R.J. Buresh, and D.P. Garrity. 1993. Nitrate dynamics during the aerobic soil phase in lowland rice-based cropping systems. Soil Sci. Soc. Am. J. 57:15261532.

George, T., J.K. Ladha, D.P. Garrity, and R.J. Buresh. 1994. Legumes as nitrate catch crops during the dry-to-wet transition in lowland rice cropping systems. Agron. J. 86:267-273.

George, T., J.K. Ladha, D.P. Garrity, and R.O. Torres. 1995. Nitrogen dynamics of grain legume-weedy fallow-flooded rice sequences in the tropics. Agron. J. 87:1-6.

Ghosh, P., and A.K. Kashyap. 2003. Effect of rice cultivars on rate of N-mineralization, nitrification and nitrifier population size in an irrigated rice ecosystem. Appl. Soil Ecol. 24:27-41.

Grant, I.F., P.A. Roger, and I. Watanabe. 1985. Effect of grazer regulation and algal inoculation on photodependent nitrogen fixation in a wetland rice field. Biol. Fertil. Soils 1:61-72.

Griggs, B.R., R.J. Norman, C.E. Wilson, Jr., and N.A. Slaton. 2007 Ammonia volatilization and nitrogen uptake for conventional and conservation tilled dry-seeded, delayedflood rice. Soil Sci. Soc. Am. J. 71:745-751.

Hanson, G.C., P.M. Groffman, and A.J. Gold. 1994. Denitrification in riparian wetlands receiving high and low groundwater nitrate inputs. J. Environ. Qual. 23:917-922.

Hu, R., J. Cao, J. Huang, S. Peng, J. Huang, X. Zhong, Y. Zou, J. Yang, and R.J. Buresh. 2007. Farmer participatory testing of standard and modified site-specific nitrogen management for irrigated rice in China. Agric. Syst. 94:331-340.

Hua, X., X. Guangxi, Z.-C. Cai, and H. Tsuruta. 1997. Nitrous oxide emissions from three rice paddy fields in China. Nutr. Cycling Agroecosyst. 49:23-28. 
Humphreys, E., P.M. Chalk, W.A. Muirhead, F.M. Melhuish, and R.J.G. White. 1987a. Effects of time of urea application on combine-sown calrose rice in south-east Australia. III. Fertilizer nitrogen recovery, efficiency of fertilization and soil nitrogen supply. Aust. J. Agric. Res. 38:129-138.

Humphreys, E., W.A. Muirhead, F.M. Melhuish, R.J.G. White, P.M. Chalk, and L.A. Douglas. $1987 \mathrm{~b}$. Effects of time of urea application on combine-sown calrose rice in southest Australia. II. Mineral nitrogen transformations in the soil-water system. Aust. J. Agric. Res. 38:113-127.

Humphreys, E., P.M. Chalk, W.A. Muirhead, and R.J.G. White. 1992. Nitrogen fertilization of dry-seeded rice in south-east Australia. Fertil. Res. 31:221-234.

Humphreys, E., J.R. Freney, W.A. Muirhead, O.T. Denmead, J.R. Simpson, R. Leuning, A.C.F. Trevitt, W.N. Obcemea, R. Wetselaar, and G.X. Cai. 1988. Loss of ammonia after application of urea at different times to dry-seeded, irrigated rice. Fertil. Res. 16:47-57.

Hussain, F., K.F. Bronson, Yadvinder-Singh, Bijay-Singh, and S. Peng. 2000. Use of chlorophyll meter sufficiency indices for nitrogen management of irrigated rice in Asia. Agron. J. 92:875-879.

International Rice Research Institute. 2007. Site-specific nutrient management. Available at www.irri.org/irrc/ssnm. Accessed 30 Aug. 2007.

Jayaweera, G.R., and D.S. Mikkelsen. 1990. Ammonia volatilization from flooded soil systems: A computer model. II. Theory and model results. Soil Sci. Soc. Am. J 54:1456-1462.

John, P.S., R.J. Buresh, R. Prasad, and R.K. Pandey. 1989. Nitrogen gas $\left(\mathrm{N}_{2}+\mathrm{N}_{2} \mathrm{O}\right)$ flux from urea applied to lowland rice as affected by green manure. Plant Soil 119:7-13.

Kai, H., W. Masayna, and Y. Yamada. 1984. Nitrogen behavior in tropical wetland rice soils. 1. Nitrogen-supplying capacities. Fertil. Res. 5:259-271.

Katyal, J.C., B. Singh, V.K. Sharma, and E.T. Graswell. 1985. Efficiency of some modified urea fertilizer for lowland rice grown on a permeable soil. Fertil. Res. 6:279-290.

Keerthisinghe, D.G., J.R. Freney, and A.R. Mosier. 1993. Effect of wax-coated calcium carbide and nitrapyrin on nitrogen loss and methane emission from dry-seeded flooded rice. Biol. Fertil. Soils 16:71-75.

Keerthisinghe, D.G., X.J. Lin, Q.X. Luo, and A.R. Mosier. 1996. Effect of encapsulated calcium carbide and urea application methods on denitrification and $\mathrm{N}$ losses from flooded rice. Fertil. Res. 45:31-36.

Keerthisinghe, G., S.K. De Datta, and K. Mengel. 1985. Importance of exchangeable and nonexchangeable soil $\mathrm{NH}_{4}^{+}$in nitrogen nutrition of lowland rice. Soil Sci. 140:194-201.

Keerthisinghe, G., K. Mengel, and S.K. De Datta. 1984. The release of nonexchangeable ammonium $\left({ }^{15} \mathrm{~N}\right.$ labeled) in wetland rice soils. Soil Sci. Soc. Am. J. 48:291-294.

Kristensen, E., M.H. Jensen, G.T. Banta, K. Hansen, M. Holmer, and G.M. King. 1998. Transformation and transport of inorganic nitrogen in sediments of a southeast Asian mangrove forest. Aquat. Microb. Ecol. 15:165-175.

Kundu, D.K., and J.K. Ladha. 1995. Enhancing soil nitrogen use and biological nitrogen fixation in wetland rice. Exp. Agric. 31:261-277.

Kundu, D.K., and J.K. Ladha. 1997. Effect of growing rice on nitrogen mineralization in flooded soil. Soil Sci. Soc. Am. J. 61:839-845.

Kundu, D.K., and J.K. Ladha. 1999. Sustaining productivity of lowland rice soils: Issues and options related to N availability. Nutr. Cycling Agroecosyst. 53:19-33.

Ladha, J.K., D. Dawe, T.S. Ventura, U. Singh, W. Ventura, and I. Watanabe. 2000. Long-term effects of urea and green manure on rice yields and nitrogen balance. Soil Sci. Soc. Am. J. 64:1993-2001.

Ladha, J.K., D.K. Kundu, M.G. Angelo-van Coppenolle, M.B. Peoples, V.R. Carangal, and P.J. Dart. 1996. Legume productivity and soil nitrogen dynamics in lowland rice-based cropping systems. Soil Sci. Soc. Am. J. 60:183-192.

Ladha, J.K., and P.M. Reddy. 2003. State of knowledge of nitrogen fixation in rice and future prospects. Plant Soil 252:151-168.

Ladha, J.K., A.T. Padre, G.C. Punzalan, I. Watanabe, and S.K. De Datta. 1988. Ability of wetland rice to stimulate biological nitrogen fixation and utilize soil nitrogen. p. 747-752. In H. Bothe et al. (ed.) Nitrogen fixation: Hundred years after. Gustav Fischer, Stuttgart, New York.

Linquist, B.A., S.M. Brouder, and J.E. Hill. 2006. Winter straw and water management effects on soil nitrogen dynamics in California rice systems. Agron. J. 98:1050-1059.

Lusby, F.E., M.M. Gibbs, A.B. Cooper, and K. Thompson. 1998. The fate of groundwater ammonium in a lake edge wetland. J. Environ. Qual. 27:459-466. 
Ma, L.S. 1997. Nitrogen management and environmental and crop quality. p. 303-321. In Z.L. Zhu et al. (ed.) Nitrogen in soils of China. Kluwer Academic Publ., Dordrecht, The Netherlands.

Mahieu, N., D.C. Olk, and E.W. Randall. 2000. Accumulation of heterocyclic nitrogen in humified organic matter: A ${ }^{15} \mathrm{~N}-\mathrm{NMR}$ study of lowland rice soils. Eur. J. Soil Sci. 51:379-389.

Mandal, B., P.L.G. Vlek, and L.N. Mandal. 1999. Beneficial effects of blue-green algae and Azolla, excluding supplying nitrogen, on wetland rice fields: A review. Biol. Fertil. Soils 28:329-342.

Manguiat, I.J., G.B. Mascariña, J.K. Ladha, R.J. Buresh, and J. Tallada. 1994. Prediction of nitrogen availability and rice yield in lowland soils: Nitrogen mineralization parameters. Plant Soil 160:131-137.

Meyer, M.L., P.R. Bloom, and J. Grava. 1989. Transformation and losses of applied nitrogen15 labeled ammonium in a flooded organic soil. Soil Sci. Soc. Am. J. 53:79-85.

Mikkelsen, D.S. 1987. Nitrogen budgets in flooded soils used for rice production. Plant Soil 100:71-97.

Mikkelsen, D.S., S.K. De Datta, and W.N. Obcemea. 1978. Ammonia volatilization losses from flooded rice soils. Soil Sci. Soc. Am. J. 42:725-730.

Mitsui, S. 1955. Inorganic nutrition, fertilisation, and soil amelioration for lowland rice. Yokendo Ltd., Tokyo, Jpn.

Mohanty, S.K., and A.R. Mosier. 1990. Nitrification-denitrification in flooded rice soils. $\mathrm{p}$ 326-331. Trans. 14th Int. Congr. Soil Sci., Vol. 4, Kyoto, Japan.

Mohanty, S.K., U. Singh, V. Balasubramanian, and K.P. Jha. 1999. Nitrogen deep-placement technologies for productivity, profitability, and environmental quality of rainfed lowland rice systems. Nutr. Cycling Agroecosyst. 53:43-57.

Mosier, A.R., S.K. Mohanty, A. Bhadrachalam, and S.P. Chakravorti. 1990. Evolution of dinitrogen and nitrous oxide from the soil to the atmosphere through rice plants. Biol. Fertil. Soils 9:61-67.

Muirhead, W.A., S.K. De Datta, P.A. Roger, and R.M. Gusto. 1989. Effect of algicides on urea fertilizer efficiency in transplanted rice. I. Floodwater chemistry and biota. Fertil. Res. 21:95-107.

Mulder, A., A.A. van de Graaf, L.A. Robertson, and J.G. Kuenen. 1995. Anaerobic ammonium oxidation discovered in a denitrifying fluidized bed reactor. FEMS Microbiol. Ecol. $16: 177-184$

$\mathrm{Ni}$, W.Z., and Z.L. Zhu. 2004. Evidence of $\mathrm{N}_{2} \mathrm{O}$ emission and gaseous nitrogen losses through nitrification-denitrification induced by rice plants (Oryza sativa L.). Biol. Fertil. Soils 40:211-214.

Norman, R.J., J.T. Gilmour, and B.R. Wells. 1990. Mineralization of nitrogen from nitrogen-15 labeled crop residues and utilization by rice. Soil Sci. Soc. Am. J. 54:1351-1356.

Oertli, J.L. 1980. Controlled-release fertilizers. Fertil. Res. 1:103-123.

Olk, D.C., G. Brunetti, and N. Senesi. 1999a. Organic matter in double-cropped lowland rice soils: Chemical and spectroscopic properties. Soil Sci. 164:633-649.

Olk, D.C., G. Brunetti, and N. Senesi. 2000. Decrease in humification of organic matter with intensified lowland rice cropping: A wet chemical and spectroscopic investigation. Soil Sci. Soc. Am. J. 64:1337-1347.

Olk, D.C., K.G. Cassman, N. Mahieu, and E.W. Randall. 1998. Conserved chemical properties of young humic acid fractions in tropical lowland soil under intensive irrigated rice cropping. Eur. J. Soil Sci. 49:337-349.

Olk, D.C., K.G. Cassman, E.W. Randall, P. Kinchesh, L.J. Sanger, and J.M. Anderson. 1996. Changes in chemical properties of organic matter with intensified rice cropping in tropical lowland soil. Eur. J. Soil Sci. 47:293-303.

Olk, D.C., K.G. Cassman, G. Simbahan, P.C. Sta. Cruz, S. Abdulrachman, R. Nagarajan, P.S. Tan, and S. Satawathananont. 1999b. Interpreting fertilizer-use efficiency in relation to soil nutrient-supplying capacity, factor productivity, and agronomic efficiency. Nutr. Cycling Agroecosyst. 53:35-41.

Olk, D.C., M.I. Samson, and P. Gapas. 2007. Inhibition of nitrogen mineralization in young humic fractions by anaerobic decomposition of rice crop residues. Eur. J. Soil. Sci. 58:270-281.

Padilla, J.L. 2001. Analysis of long-term changes in rice productivity under intensive cropping systems in the tropics and improvement of nitrogen use efficiency. Ph.D. diss. Grad. School of Agric., Kyoto Univ., Kyoto, Jpn.

Padilla, J.L., R.J. Buresh, S.K. De Datta, and E.U. Bautista. 1990. Incorporation of urea in puddled rice soils as affected by tillage implements. Fertil. Res. 26:169-178. 
Pampolino, M.F., E.V. Laureles, H.C. Gines, and R.J. Buresh. 2008. Soil carbon and nitrogen changes as affected by fertilization in long-term continuous lowland rice cropping. Soil Sci. Soc Am. J. (In press).

Pampolino, M.F., I.J. Manguiat, S. Ramanathan, H.C. Gines, P.S. Tan, T.T.N. Chi, R. Rajendran, and R.J. Buresh. 2007. Environmental impact and economic benefits of site-specific nutrient management (SSNM) in irrigated rice systems. Agric. Syst. 93:1-24.

Pasandaran, E., B. Gultom, J.S. Adiningsih, H. Apsari, and S. Rochayati. 1999. Government policy support for technology promotion and adoption: A case study of urea tablet technology in Indonesia. Nutr. Cycling Agroecosyst. 53:113-119.

Patrick, W.H., Jr. 1982. Nitrogen transformations in submerged soils. p. 449-465. In F.J. Stevenson et al. (ed.) Nitrogen in agricultural soils. ASA, CSSA, and SSSA, Madison, WI.

Patrick, W.H., Jr., and K.R. Reddy. 1976. Nitrification-denitrification reactions in flooded soils and water bottoms: Dependence on oxygen supply and ammonium diffusion. J. Environ. Qual. 5:469-472.

Patrick, W.H., Jr., and R. Wyatt. 1964. Soil nitrogen loss as a result of alternate submergence and drying. Soil Sci. Soc. Am. Proc. 28:647-653.

Payne, W.J. 1970. Energy yields and growth of heterotrophs. Annu. Rev. Microbiol. 24:17-52.

Peng, S., and K.G. Cassman. 1998. Upper thresholds of nitrogen uptake rates and associated nitrogen fertilizer efficiencies in irrigated rice. Agron. J. 90:178-185.

Peng, S., F.V. Garcia, R.C. Laza, and K.G. Cassman. 1993. Adjustment for specific leaf weight improves chlorophyll meter's estimate of rice leaf nitrogen concentration. Agron. J. 85:987-990.

Peng, S., F.V. Garcia, R.C. Laza, A.L. Sanico, R.M. Visperas, and K.G. Cassman. 1996. Increased $\mathrm{N}$-use efficiency using a chlorophyll meter on high yielding irrigated rice. Field Crops Res. 47:243-252.

Phongpan, S., and A.R. Mosier. 2003. Effect of crop residue management on nitrogen dynamics and balance in a lowland rice cropping system. Nutr. Cycling Agroecosyst. 66:133-142.

Ponnamperuma, F.N. 1972. The chemistry of submerged soils. Adv. Agron. 24:29-96.

Reddy, K.R., and W.H. Patrick, Jr. 1977. Effect of placement and concentration of applied $\mathrm{NH}_{4}{ }^{+}-\mathrm{N}$ on nitrogen loss from flooded soil. Soil Sci. 123:142-148.

Reddy, K.R., and W.H. Patrick, Jr. 1986. Denitrification losses in flooded rice fields. Fertil. Res. 9:99-116.

Reddy, K.R., W.H. Patrick, Jr., and C.W. Lindau. 1989. Nitrification-denitrification at the plant root-sediment interface in wetlands. Limnol. Oceanogr. 34:1004-1013.

Reddy, K.R., W.H. Patrick, Jr., and R.E. Phillips. 1976. Ammonium diffusion as a factor in nitrogen loss from flooded soils. Soil Sci. Soc. Am. J. 40:528-533.

Reddy, K.R., W.H. Patrick, Jr., and R.E. Phillips. 1978. The role of nitrate diffusion in determining the order and rate of denitrification in flooded soil: I. Experimental results. Soil Sci. Soc. Am. J. 42:268-272.

Regina, K., J. Silvola, and P.J. Martikainen. 1999. Short-term effects of changing water table on $\mathrm{N}_{2} \mathrm{O}$ fluxes from peat monoliths from natural and drained boreal peatlands. Glob. Change Biol. 5:183-189.

Roger, P.A. 1996. Biology and management of the floodwater ecosystem in ricefields. IRRI, Los Baños, Philippines.

Roger, P.A., S.A. Kulasooriya, A.C. Tirol, and E.T. Craswell. 1981. Deep placement: A method of nitrogen fertilizer application compatible with algal nitrogen fixation in wetland rice soils. Plant Soil 57:137-142.

Roger, P.A., and J.K. Ladha. 1992. Biological $\mathrm{N}_{2}$ fixation in wetland rice fields: Estimation and contribution to nitrogen balance. Plant Soil 141:41-55.

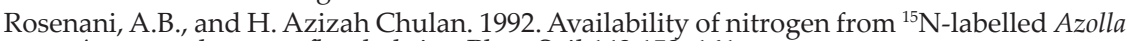
pinnata and urea to flooded rice. Plant Soil 143:153-161.

Sah, R.N., and D.S. Mikkelsen. 1983. Availability and utilization of fertilizer nitrogen by rice under alternate flooding. I. Kinetics of available nitrogen under rice culture. Plant Soil 75:221-226.

Samra, J.S., Bijay-Singh, and K. Kumar. 2003. Managing Crop residues in the rice-wheat system of the Indo-Gangetic plain. p. 173-195. In J.K. Ladha et al. (ed.) Improving the productivity and sustainability of rice-wheat systems: Issues and impacts. ASA Spec. Publ. 65. ASA, CSSA, and SSSA, Madison, WI.

Samson, M.I., R.J. Buresh, and S.K. De Datta. 1990. Evolution and soil entrapment of nitrogen gases formed by denitrification in flooded soil. Soil Sci. Plant Nutr. 36:299-307. 
Santiago-Ventura, T., M. Bravo, C. Daez, V. Ventura, I. Watanabe, and A.A. App. 1986. Effects of $\mathrm{N}$-fertilizers, straw, and dry fallow on the nitrogen balance of a flooded soil planted with rice. Plant Soil 93:405-411.

Savant, N.K., P.S. Ongkingco, F.D. Garcia, S.S. Dhane, R.R. Khadse, S.A. Chavan, and K.S. Rao. 1992. Agronomic performance of urea briquette applicator in transplanted rice. Fertil. Res. 32:139-142.

Scherer, H.W., and Y.S. Zhang. 1999. Studies on the mechanisms of fixation and release of ammonium in paddy soils after flooding. I. Effect of iron oxides on ammonium fixation. J. Plant Nutr. Soil Sci. 162:593-597.

Scherer, H.W., and Y.S. Zhang. 2002. Mechanisms of fixation and release of ammonium in paddy soils after flooding. III. Effect of the oxidation state of octahedral Fe on ammonium fixation. J. Plant Nutr. Soil Sci. 165:185-189.

Schmidt, I., O. Sliekers, M. Schmid, E. Bock, J. Fuerst, J.G. Kuenen, M.S.M. Jetten, and M. Strous. 2003. New concept of microbial treatment processes for the nitrogen removal in wastewater. FEMS Microbiol. Rev. 27:481-492.

Schneiders, M., and H.W. Scherer. 1998. Fixation and release of ammonium in flooded rice soils as affected by redox potential. Eur. J. Agron. 8:181-189.

Schnier, H.F. 1995. Significance of timing and method of N fertilizer application for the Nuse efficiency in flooded tropical rice. Fertil. Res. 42:129-138.

Schnier, H.F., S.K. De Datta, A.M. Fagi, M. Eaqub, Faruque Ahmed, R. Tejasarwana, and A. Mazid. 1993. Yield response of wetland rice to band placement of urea solution to various soils in the tropics. Fertil. Res. 36:221-227.

Schnier, H.F., S.K. De Datta, and K. Mengel. 1987a. Dynamics of ${ }^{15} \mathrm{~N}-l a b e l e d$ ammonium sulfate in various inorganic and organic soil fractions of wetland rice soils. Biol. Fertil. Soils 4:171-177.

Schnier, H.F., M. Dingkuhn, S.K. De Datta, E.P. Marqueses, and J.E. Faronilo. 1990. Nitrogen15 balance in transplanted and direct-seeded flooded rice as affected by different methods of urea application. Biol. Fertil. Soils 10:89-96.

Schnier, H.F., M. Dingkuhn, S.K. De Datta, K. Mengel, and J.E. Faronilo. 1987b. Nitrogen fertilization of direct-seeded flooded vs. transplanted rice: I. Nitrogen uptake, photosynthesis, growth, and yield. Crop Sci. 30:1276-1284.

Scholten, J.H.M. 1992. Increasing urea-N efficiency for transplanted lowland rice by pneumatic injection: Yield and economics at the farm level. Fertil. Res. 33:107-114.

Seitzinger, S.P. 1994. Linkages between organic matter mineralization and denitrification in eight riparian wetlands. Biogeochemistry 25:19-39.

Sharif Zia, M., and S.A. Waring. 1987. Balance sheet of ${ }^{15} \mathrm{~N}$ labelled urea applied to rice in three Australian vertisols differing in soil organic carbon. Fertil. Res. 12:53-65.

Sharma, G., S.K. Patil, R.J. Buresh, V.N. Mishra, R.O. Das, S.M. Haefele, and L.K. Shrivastava. 2005. Rice establishment method affects nitrogen use and crop production of rice-legume systems in drought-prone eastern India. Field Crops Res. 92:11-33.

Sharma, K.N., A.L. Bhandari, M.L. Kapur, and D.S. Rana. 1985. Influence of growing various crops in five different fixed rotations on the changes in nitrate and total nitrogen content of soils. J. Agric. Sci. (Cambridge) 104:609-613.

Sharma, P.K., and S.K. De Datta. 1986. Physical properties and processes of puddled rice soils. Adv. Soil Sci. 5:139-178.

Shoji, S., and H. Kanno. 1994. Use of polyolefin-coated fertilizers for increasing fertilizer efficiency and reducing nitrate leaching and nitrous oxide emissions. Fertil. Res. 39:147-152.

Shrestha, R.K., and J.K. Ladha. 1996. Genotypic variation in promotion of rice dinitrogen fixation as determined by nitrogen-15 dilution. Soil Sci. Soc. Am. J. 60:1815-1821.

Shrestha, R.K., and J.K. Ladha. 1998. Nitrate in groundwater and integration of nitrogencatch crop in rice-sweet pepper cropping system. Soil Sci. Soc. Am. J. 62:1610-1619.

Shrestha, R.K., and J.K. Ladha. 2000. Recycling of residual soil nitrogen in a lowland ricesweet pepper cropping system. Soil Sci. Soc. Am. J. 64:1689-1698.

Simpson, J.R., J.R. Freney, W.A. Muirhead, and R. Leuning. 1985. Effects of phenylphosphorodiamidate and dicyandiamide on nitrogen loss from flooded rice. Soil Sci. Soc. Am. J. 49:1426-1431.

Simpson, J.R., W.A. Muirhead, K.H. Bowmer, G.X. Cai, and J.R. Freney. 1988. Control of gaseous nitrogen losses from urea applied to flooded rice soils. Fertil. Res. 18:31-47.

Singh, U., and R.J. Buresh. 1994. Fertilizer technology for increased fertilizer efficiency in paddy rice fields. p. 643-656. In Trans. 15th World Congress Soil Sci., Vol. 5a, Acapulco, Mexico. 
Singh, U., S.K. Patil, R.O. Das, J.L. Padilla, V.P. Singh, and A.R. Pal. 1999. Nitrogen dynamics and crop growth on an alfisol and a vertisol under rainfed lowland rice-based cropping system. Field Crops Res. 61:237-252.

Stanford, G., J.O. Legg, S. Dzienia, and E.C. Simpson, Jr. 1975. Denitrification and associated nitrogen transformations in soils. Soil Sci. 120:147-152.

Shukla, A.K., J.K. Ladha, V.K. Singh, B.S. Dwivedi, V. Balasubramanian, R.J. Gupta, S.K. Sharma, Y. Singh, H. Pathak, P.S. Pandey, A.T. Padre, and R.L. Yadav. 2004. Calibrating the leaf color chart for nitrogen management in different genotypes of rice and wheat in a systems perspective. Agron. J. 96:1606-1621.

Thamdrup, B., and T. Dalsgaard. 2002. Production of $\mathrm{N}_{2}$ through anaerobic oxidation coupled to nitrate reduction in marine sediments. Appl. Environ. Microbiol. 68:1312-1318.

Thuy, N.H. 2004. Yield trends, soil fertility changes, and indigenous nitrogen supply as affected by crop and soil management in intensive irrigated rice systems. Ph.D. diss. Univ. of the Philippines at Los Baños, Los Baños, Philippines.

Thuy, N.H., Y. Shan, Bijay-Singh, K. Wang, Z. Cai, Yadvinder-Singh, and R.J. Buresh. 2008. Nitrogen supply in rice-based cropping systems as affected by crop residue management. Soil Sci. Soc. Am. J. (In press).

Tobias, C.R., I.C. Anderson, E.A. Canuel, and S.A. Macko. 2001. Nitrogen cycling through a fringing marsh-aquifer ecotone. Mar. Ecol. Prog. Ser. 210:25-39.

Tripathi, B.P., J.K. Ladha, J. Timsina, and S.R. Pascua. 1997. Nitrogen dynamics and balance in intensified rainfed lowland rice-based cropping systems. Soil Sci. Soc. Am. J. 61:812-821.

Tusneem, M.E., and W.H. Patrick, Jr. 1971. Nitrogen transformations in waterlogged soil. Louisiana State Univ. Agric. Exp. Stn. Bull. 657:1-75.

Van Groenigen, J.W., E.G. Burns, J.M. Eadie, W.R. Horwath, and C. van Kessel. 2003. Effects of foraging waterfowl in winter flooded rice fields on weed stress and residue decomposition. Agric. Ecosyst. Environ. 95:289-296.

Van Hoewyk, D., P.M. Groffman, E. Kiviat, G. Mihocko, and G. Stevens. 2000. Soil nitrogen dynamics in organic and mineral soil calcareous wetlands in eastern New York. Soil Sci. Soc. Am. J. 64:2168-2173.

Verma, T.S., and R.M. Bhagat. 1992. Impact of rice straw management practices on yield, nitrogen uptake and soil properties in a wheat-rice rotation in northern India. Fertil. Res. 33:97-106.

Villegas-Pangga, G., G. Blair, and R. Lefroy. 2000. Measurement of decomposition and associated nutrient release from straw (Oryza sativa L.) of different rice varieties using perfusion system. Plant Soil 223:1-11.

Vlek, P.L.G., B.H. Byrnes, and E.T. Craswell. 1980. Effect of urea placement on leaching losses of nitrogen from flooded rice soils. 1980. Plant Soil 54:441-449.

Vlek, P.L.G., and E.T. Craswell. 1979. Effect of nitrogen source and management on ammonia volatilization losses from flooded rice-soil systems. Soil Sci. Soc. Am. J. 43:352-358.

Vlek, P.L.G., and E.T. Craswell. 1981. Ammonia volatilization from flooded soils. Fertil. Res. 2:227-245.

Vlek, P.L.G., M.Y. Diakite, and H. Mueller. 1995. The role of Azolla in curbing ammonia volatilization from flooded rice systems. Fertil. Res. 42:165-174.

Vlek, P.L.G., and J.M. Stumpe. 1978. Effects of solution chemistry and environmental conditions on ammonia volatilization losses from aqueous systems. Soil Sci. Soc. Am. J. 42:416-421.

Waksman, S.A. 1929. Chemical and microbiological principles underlying the decomposition of green manures in the soil. J. Am. Soc. Agron. 21:1-18.

Wang, G.H., A. Dobermann, C. Witt, Q.Z. Sun, and R.X. Fu. 2001a. Performance of site-specific nutrient management for irrigated rice in southeast China. Agron. J. 93:869-878.

Wang, G.H., Q. Sun, R. Fu, X. Huang, X. Ding, J. Wu, Y. He, A. Dobermann, and C. Witt. 2004. Site-specific nutrient management in irrigated rice systems of Zhejiang province, China. p. 243-263. In A. Dobermann et al. (ed.) Increasing productivity of intensive rice systems through site-specific nutrient management. Scientific Publ., Enfeld, NH (USA) and IRRI, Los Baños, Philippines.

Wang, W.J., P.M. Chalk, D. Chen, and C.J. Smith. 2001b. Nitrogen mineralisation, immobilisation and loss, and their role in determining differences in net nitrogen production during waterlogged and aerobic incubation of soils. Soil Biol. Biochem. 33:1305-1315.

Wang, G., Q.C. Zhang, C. Witt, and R.J. Buresh. 2007. Opportunities for yield increases and environmental benefits through site-specific nutrient management in rice systems in Zhejiang province, China. Agric. Syst. 94:801-806. 
Watanabe, I. 1982. Azolla-anabaena symbiosis-its physiology and use in tropical agriculture. p. 169-185. In Y.R. Dommergues and H.G. Diem (ed.) Microbiology of tropical soils and plant productivity. Martinus Nijhoff/Dr W. Junk Publ., The Hague, Boston, and London.

Watanabe, I., W. Ventura, G. Mascariña, and D.L. Eskew. 1989. Fate of Azolla spp. and urea nitrogen applied to wetland rice (Oryza sativa L.). Biol. Fertil. Soils 8:102-110.

Wen, Q.X., and L.L. Cheng. 1997. Fixation and release of ammonium. p. 67-86. In Z.L. Zhu et al. (ed.) Nitrogen in soils of China. Kluwer Academic Publ., Dordrecht, The Netherlands.

Witt, C., U. Biker, C.C. Galicia, and J.C.G. Ottow. 2000a. Dynamics of soil microbial biomass and nitrogen availability in a flooded rice soil amended with different $C$ and $N$ sources. Biol. Fertil. Soils 30:521-527.

Witt C., R.J. Buresh, S. Peng, V. Balasubramanian, and A. Dobermann. 2007. Nutrient management. p. 1-45. In T. Fairhurst et al. (ed.) Rice: A practical guide to nutrient management. International Rice Research Institute (IRRI), Los Baños, Philippines, International Plant Nutrition Institute (IPNI), and International Potash Institute (IPI), Singapore.

Witt, C., K.G. Cassman, D.C. Olk, U. Biker, S.P. Liboon, M.I. Samson, and J.C.G. Ottow. 2000b. Crop rotation and residue management effects on carbon sequestration, nitrogen cycling and productivity of irrigated rice systems. Plant Soil 225:263-278.

Witt, C., K.G. Cassman, J.C.G. Ottow, and U. Biker. 1998. Soil microbial biomass and nitrogen supply in an irrigated lowland rice soil as affected by crop rotation and residue management. Biol. Fertil. Soils 28:71-80.

Witt, C., and A. Dobermann. 2004. Toward a decision support system for site-specific nutrient management. p. 359-395. In A. Dobermann et al. (ed.) Increasing productivity of intensive rice systems through site-specific nutrient management. Scientific Publ., Enfeld, NH (USA) and IRRI, Los Baños, Philippines.

Witt, C., A. Dobermann, S. Abdulrachman, H.C. Gines, G. Wang, R. Nagarajan, S. Satawatananont, T.T. Son, P.S. Tan, L.V. Tiem, G.C. Simbahan, and D.C. Olk. 1999. Internal nutrient efficiencies of irrigated lowland rice in tropical and subtropical Asia. Field Crops Res. 63:113-138.

Witt, C., J.M.C.A Pasuquin, R. Mutters, R., and R.J. Buresh. 2005. New leaf color chart for effective nitrogen management in rice. Better Crops 89 (1):36-39.

Xing, G.X., and Z.L. Zhu. 2000. An assessment of N loss from agricultural fields to the environment in China. Nutr. Cycling Agroecosyst. 57:67-73.

Yadav, R.L. 2003. Assessing on-farm efficiency and economics of fertilizer N, P and K in rice wheat systems of India. Field Crops Res. 81:39-51.

Yadvinder-Singh, C.S. Khind, and Bijay-Singh. 1991. Efficient management of leguminous green manures in wetland rice. Adv. Agron. 45:135-189.

Yang, W.H., S. Peng, J. Huang, A.L. Sanico, R.J. Buresh, and C. Witt. 2003. Using leaf color charts to estimate leaf nitrogen status of rice. Agron. J. 95:212-217.

Zak, D.R., and D.F. Grigal. 1991. Nitrogen mineralization, nitrification and denitrification in upland and wetland ecosystems. Oecologia 88:189-196.

Zhang, Y.S., and H.W. Scherer. 1999. Ammonium fixation by clay minerals in different layers of two paddy soils after flooding. Biol. Fertil. Soils 29:152-156.

Zhang, Y.S., and H.W. Scherer. 2000. Mechanisms of fixation and release of ammonium in paddy soils after flooding. II. Effect of transformation of nitrogen forms on ammonium fixation. Biol. Fertil. Soils 31:517-521.

Zhu, J.G., Y. Han, G. Liu, Y.L. Zhang, and X.H. Shao. 2000. Nitrogen in percolation water in paddy fields with a rice/wheat rotation. Nutr. Cycling Agroecosyst. 57:75-82.

Zhu, Z.L. 1997. Fate and management of fertilizer nitrogen in agro-ecosystems. p. 239-279. In Z.L. Zhu et al. (ed.) Nitrogen in soils of China. Kluwer Academic Publ., Dordrecht, The Netherlands.

Zhu, Z.L., G.X. Cai, J.R. Simpson, S.L. Zhang, D.L. Chen, A.V. Jackson, and J.R. Freney. 1989. Processes of nitrogen loss from fertilizers applied to flooded rice fields on a calcareous soil in north-central China. Fertil. Res. 18:101-115.

Zhu, Z.L., and D.L. Chen. 2002. Nitrogen fertilizer use in China-Contributions to food production, impacts on the environment and best management strategies. Nutr. Cycling Agroecosyst. 63:117-127. 